
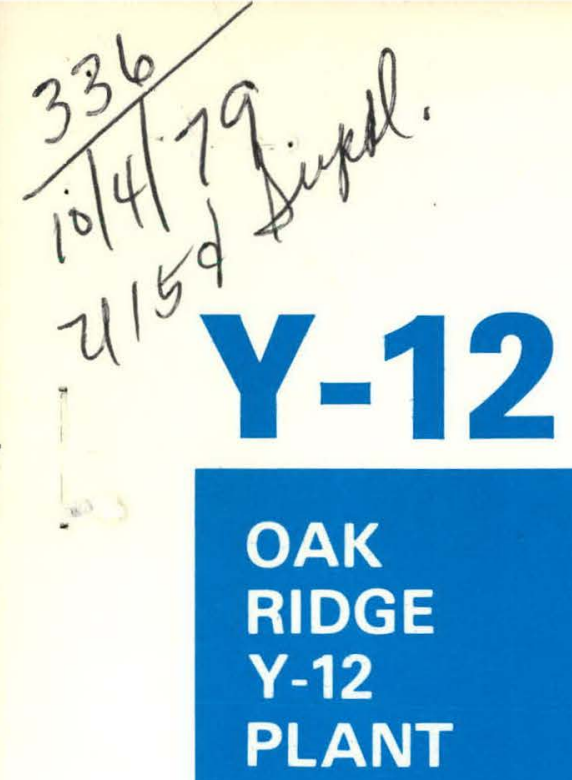

UNION CARBIDE

\section{th. 119}

Y-2182

\title{
EVALUATION OF A RANDOM DRIVER FOR Y-12 IN-PLANT APPLICATIONS
}

\section{T. E. Sampson}

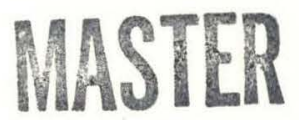

September 1979

OPERATED BY

UNION CARBIDE CORPORATION

FOR THE UNITED STATES DEPARTMENT OF ENERGY 


\section{DISCLAIMER}

This report was prepared as an account of work sponsored by an agency of the United States Government. Neither the United States Government nor any agency Thereof, nor any of their employees, makes any warranty, express or implied, or assumes any legal liability or responsibility for the accuracy, completeness, or usefulness of any information, apparatus, product, or process disclosed, or represents that its use would not infringe privately owned rights. Reference herein to any specific commercial product, process, or service by trade name, trademark, manufacturer, or otherwise does not necessarily constitute or imply its endorsement, recommendation, or favoring by the United States Government or any agency thereof. The views and opinions of authors expressed herein do not necessarily state or reflect those of the United States Government or any agency thereof. 


\section{DISCLAIMER}

Portions of this document may be illegible in electronic image products. Images are produced from the best available original document. 
Reference to a company or product name does not imply approval or recommendation of the product by Union Carbide Corporation or the Department of Energy to the exclusion of others that may meet specifications.

Printed in the United States of America. Available from National Technical Information Service

U.S. Department of Commerce

5285 Port Royal Road, Springfield, Virginia 22161

Price: Printed Copy A03; Microfiche A01

This report was prepared as an account of work sponsored by an agency of the United States Government. Neither the United States Government nor any agency thereof, nor any of their employees, nor any of their contractors, subcontractors, or their employees, makes any warranty, express or implied, nor assumes any legal liability or responsibility for any third party's use or the results of such use of any information, apparatus, product or process disclosed in this report, nor represents that its use by such third party would not infringe privately owned rights. 
Date of Issue: September 27, 1979

Distribution Category: UC-15

\title{
EVALUATION OF A RANDOM DRIVER FOR Y-12 IN-PLANT APPLICATIONS
}

\author{
T. E. Sampson \\ Y-12 Development Division
}

Oak Ridge Y-12 Plant

P. O. Box Y, Oak Ridge, Tennessee 37830

Prepared for the Department of Energy

Under US Government Contraot W-7405.ong:26 


\begin{abstract}
A random driver neutron interrogator has been evaluated for application to measurements of process residues at $Y-12$. The unit, designed and constructed at the Los Alamos Scientific Laboratory, has been demonstrated to provide rapid, accurate, and nondestructive assay of the uranium content of $\mathrm{U}_{3} \mathrm{O}_{8}$ skull oxide. and unleached solids. Accuracy [expressed as systematic error (bias)] on both material types is better than $1 \%$. A precision of $3 \%(1$ standard deviation) for skull oxide assay is equivalent to that exhibited by currently used sampling and chemical analysis techniques. This precision is limited by short-term instrument instabilities. The precision of unleached solids assay is limited by counting statistics to about $4 \%$ (1 standard deviation).
\end{abstract}




\section{CONTENTS}

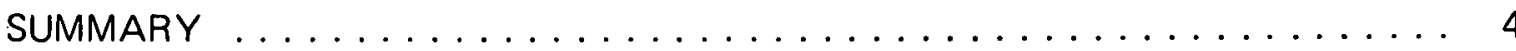

INTRODUCTION $\ldots \ldots \ldots \ldots \ldots \ldots \ldots \ldots \ldots \ldots \ldots \ldots \ldots \ldots$

Purpose ............................... 5

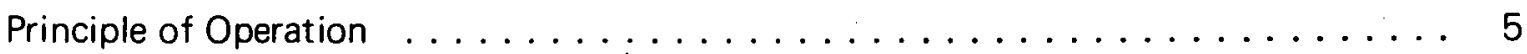

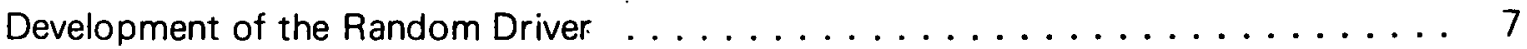

DESCRIPTION OF THE LASL/DOE RANDOM DRIVER AT Y-12 $\ldots \ldots \ldots$

Hardware ............................. 9

Electronics .............................. 10

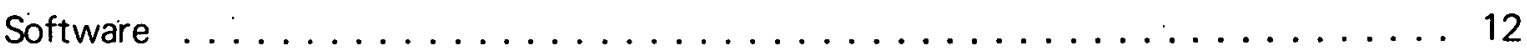

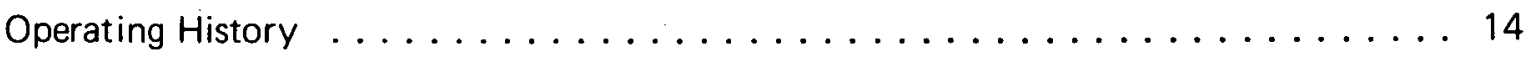

MEASUREMENTS WITH THE RANDOM DRIVER $\ldots \ldots \ldots \ldots \ldots \ldots$

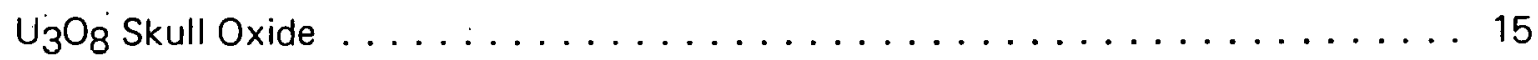

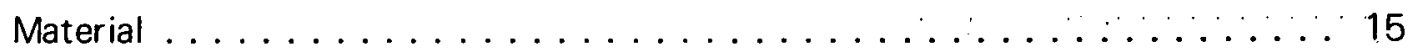

Container ........................... 15

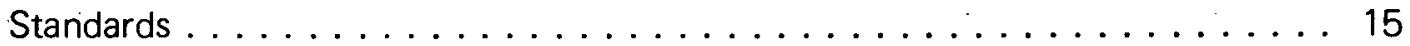

Calibration Curves .......................... 16

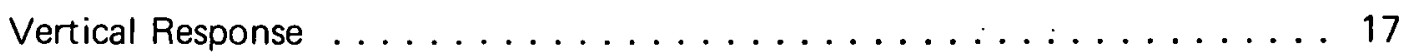

Temperature Coefficient . . . . . . . . . . . . . . . . . 19

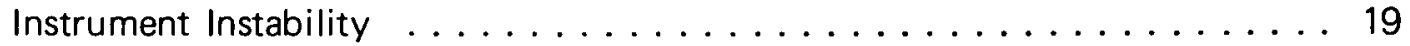

Precision of the Sampling and Chemical Analysis Results . . . . . . . . . 21

Measurements on Skull Oxide Inveritory . . . . . . . . . . . . 21

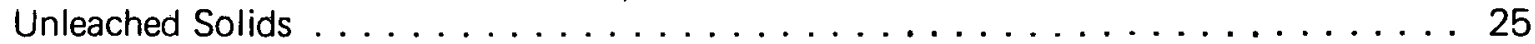

Mäterial and Containcr . . . . . . . . . . . . . . . . . . 25

Standards . . . . . . . . . . . . . . . . . . . . . 25

Measurements on Unleached Solids . . . . . . . . . . . . . . 25

Precision of the Sampling, Chemical, and Isotopic Analyses . . . . . . . . . . 26

CONCLUSIONS ............................ 29

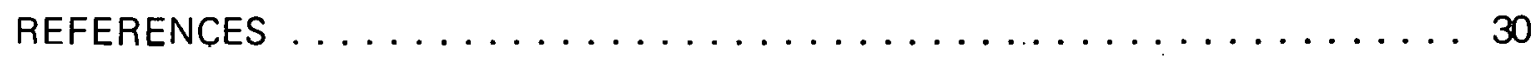

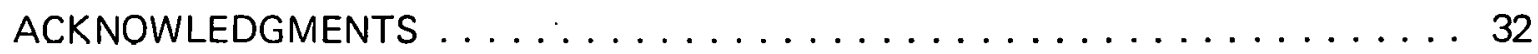

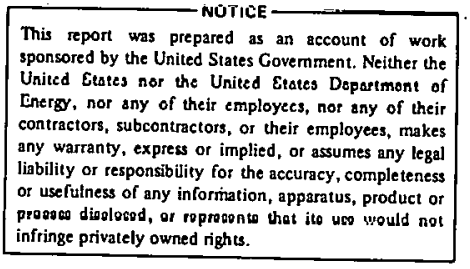




\section{SUMMARY}

Nuclear materials accountability requires the accurate measurement of the amount of uranium contained in various containers of different process residues. The nonhomogeneous character of many of these residues sometimes makes sampling and chemical analysis results nonrepresentative of the container contents. A rapid, nondestructive assay method that can measure the entire sample could reduce the sample load at the plant laboratory and provide more timely. and accurate accountability information.

A random driver or neutron interrogator has been evaluated for measurement of $\mathrm{U}_{3} \mathrm{O}_{8}$ skull oxide and unleached solids. This instrument is capable of measurement accuracy of better than $1 \%$ for both material types. However, measurement precision is somewhat poorer than this, being about 3\% (1 standard deviation, or $1 \sigma$ level) for skull oxide and 4 to $5 \%$ ( $1 \sigma$ level) for unleached solids. Short-term instrument instabilities limit the precision for. skull oxide samples (typical $8 \mathrm{~kg}$ of uranium), while counting statistics dominate the precision for the smaller unleached solids samples (typical $300 \mathrm{~g}$ of uranium).

The random driver assay results on both types of materials are equivalent to those from routine sampling and chemical analysis. This instrument can be used, with the standards developed in this program, for material accountability purposes as well as for less demanding verification measurements.

Trained, experienced personnel are needed for supervising machine operation. Routine operation can be learned easily. A planned approach to maintenance needs to be developed in order to limit the impact of downtime associated with the failure of components that cannot be repaired at $\mathrm{Y}-12$. 


\section{INTRODUCTION}

\section{PURPOSE}

This report describes the application of a random driver or neutron interrogator to the measurement of $235 \mathrm{U}$ in bulk quantities. At the Oak Ridge $Y-12$ Plant, (a) uranium-processing operations produce many different physical and chemical forms of uranium-containing materials [eg, $\mathrm{U}_{3} \mathrm{O}_{8}$ (pure and impure), $\mathrm{UO}_{2}, \mathrm{UO}_{3}, \mathrm{UF}_{4}$, uranium metal, incinerator ash, and other process residues]. Nuclear materials accountability requires that the amount of uranium contained in batches of all these material types be measured. This can be difficult for impure materials, scrap, and residue where both the $235 \mathrm{U}$ enrichment and the uranium concentration may vary. The current procedure is to physically sample these materials and determine the total uranium concentration, measured in grams of uranium per gram of total material $(\mathrm{g} \mathrm{U} / \mathrm{g})$, by chemical analysis. The $235 \mathrm{U}$ content is measured by mass spectrometry. This lengthy procedure can take up to several weeks because of the large sample load at the Y-12 Plant Laboratory. This procedure is often inaccurate for impure materials because of the problems associated with obtaining a representative sample from nonhomogeneous material. Nondestructive assay (NDA) techniques can solve some of these problems by measuring the entire sample and providing results within minutes of the measurement. These NDA techniques can reduce the sample load at the plant laboratory and also provide timely input to the DYMCAS (Dynamic Special Nuclear Materials Control and Accountability System). ${ }^{1}$ For impure materials, NDA techniques are often more accurate than sampling and chemical analysis because sampling uncertainties are eliminated.

This report will describe the random driver system and discuss its application to two material types, $\mathrm{U}_{3} \mathrm{O}_{8}$ skull oxide and incinerator ash. Its application to other types of material at $Y-12$ is still under investigation.

\section{PRINCIPLE OF OPERATION}

The random driver interrogates a $235 U$ containing sample with randomly produced fast neutrons from a ${ }^{241} \mathrm{Am} \mathrm{Li}(\alpha, n)$ neutron source $\left(\bar{E}_{n} \cong 0.5 \mathrm{MeV}\right)$. These neutrons cause fissions in the $235 \mathrm{U}$. The fission events are detected.by coincidence counting of the fission neutrons. Coincidence techniques separate the counts of the random interrogation source from those of fission events, since the random source does not contribute to the coincidence count rate. A fission event produces two or more neutrons simultaneously with several gamma rays. The number of coincidence events detected is proportional to the number of fissions, which in turn is proportional to the amount of $235 U$ in the sample.

(a) Operated by the Union Carbide Corporation's Nuclear Division for the Department of Energy. 
The type of $(\alpha, n)$ neutron source is carefully chosen so that fissions are induced only in $235 \mathrm{U}$ and not in $238 \mathrm{U}$, which has a fission threshold of about $1 \mathrm{MeV}$. The ${ }^{241} \mathrm{Am} \mathrm{Li}$ is well suited for this purpose since very few of the neutrons produced in this source $\left(E_{\max } \cong 1.5 \mathrm{MeV}\right)$ can cause fission in $238 \mathrm{U}$. To illustrate this, Figure 1 shows the fission cross sections of $235 \mathrm{U}$ and $238 \mathrm{U}$ overlaid with the ${ }^{241} \mathrm{Am} \mathrm{Li}$ relative neutron spectrum. Plutonium based $(\alpha, n)$ sources are to be avoided since spontaneous fission in 238 pu and $240 \mathrm{Pu}$ will cause a background in the coincidence channel. A fast-neutron source is desired for bulk samples because of the greater penetrability of fast neutrons relative to thermal neutrons. Thermal-neutron interrogation will also be sensitive only to $235 \mathrm{U}$, but because of the large $235 \mathrm{U}$ fission cross section at thermal energies, self-absorption will be a problem in large or high-enrichment samples. This will result in nonlinear response, although the overall sensitivity will be much higher than with fast-neutron (hard-spectrum) irradiation. Only fast-neutron interrogation has been used to date with the current unit at $Y-12$.

The random driver uses plastic scintillators to detect the coincident fission neutrons and gamma rays. These will be described in more detail later in the report.

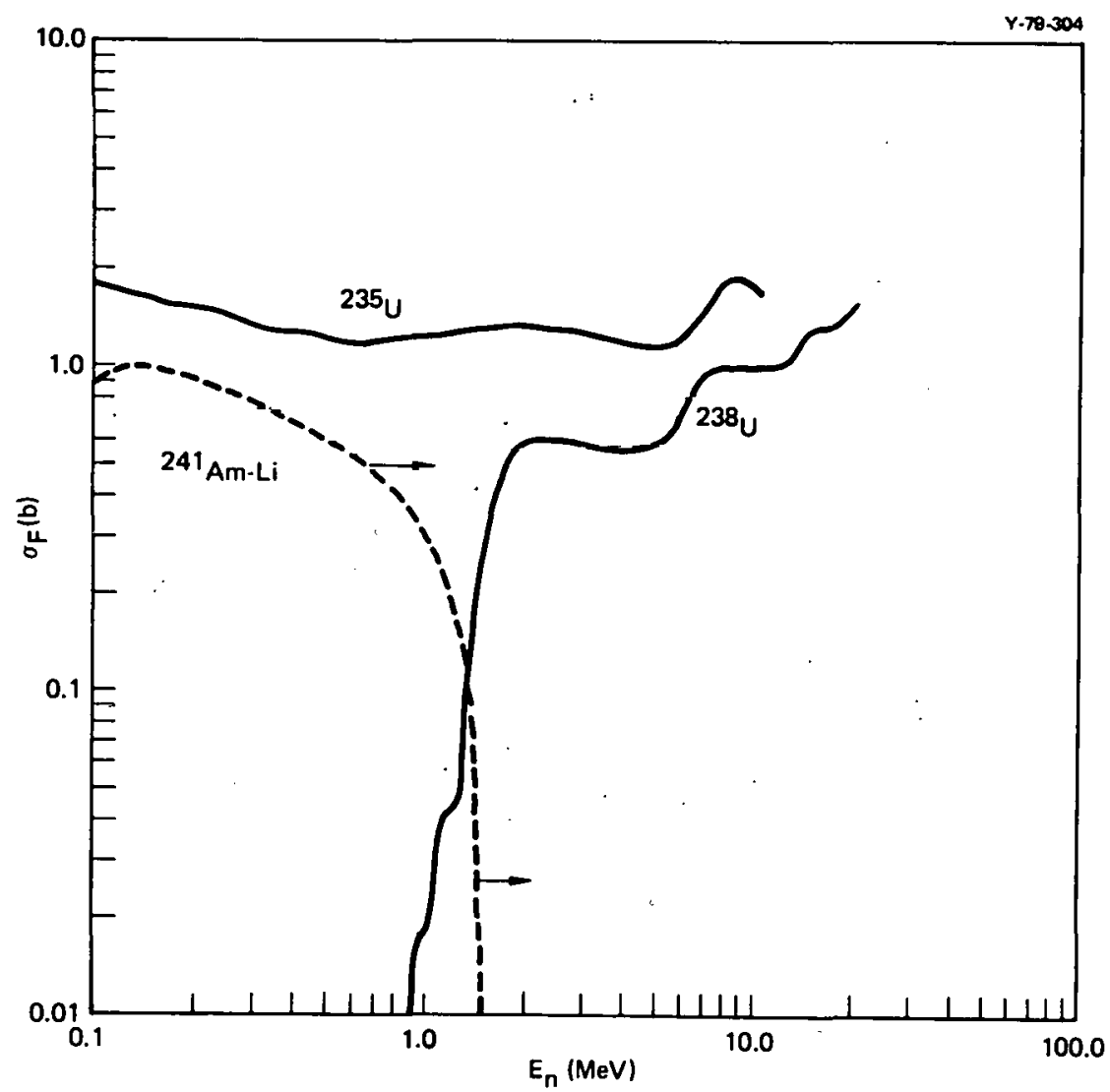

Figure 1. FISSION CROSS SECTIONS OF ${ }^{235} U$ and ${ }^{238} U$ OVERLAID WITH RELATIVE NEUTRON SPECTRUM FROM $241_{\text {Am Li }}(a, n)$ SOURCE (DASHED LINE). (This source will induce fissions primarily in ${ }^{235} U$ with a negligible number of fissions being produced in ${ }^{238} \mathrm{U}$.) 


\section{DEVELOPMENT OF THE RANDOM DRIVER}

The random driver was developed at the Los Alamos Scientific Laboratory (LASL) by Foley and co-workers starting in 1971 (US Patent 3,736,429). The development of several generations of the instrument is documented in the progress reports of the Nuclear Safequards Research and Development Program at Los Alamos. 2-18

Versions of the instrument have been field tested at Goodyear Atomic (Portsmouth Gaseous Diffusion Plant), 6 the LASL Uranium Recovery Facility, $8-10$ Savannah River Plant, ${ }^{13}$ and General Electric. ${ }^{12,14}$ One of the first field tests took place at $Y-12$ in. $1972 .{ }^{19}$

Improvements in the instrument design have taken place in many areas. Initially, a single interrogation source was vertically translated past the sample. This moving source has been replaced by multiple fixed sources; the current $Y-12$ model contains two. The size of the sample chamber influences the sensitivity. Versions with a smaller sample chamber than the one at $\mathrm{Y}-12$ have exhibited a sensitivity ten times greater than that of the $\mathrm{Y}-12$ unit. Units have been made both top loading (smaller samples, higher efficiency) and front loading, like the $\mathrm{Y}-12$ unit (operator convenience, larger samples).

Much effort has gone into trying to reduce the effect of the sample matrix on the assay. The presence of low- $Z$ material in the matrix moderates both the incident source neutrons and $235 U$ fission neutrons. Moderated source neutrons increase the fission rate in the sample because the $235 \mathrm{U}$ fission cross section increases as the incident neutron energy decreases. The moderated fission neutrons are detected with less efficiency, thus.lowering the response per unit mass of $235 \mathrm{U}$.

The neutron-moderation effects of low- $Z$ matrix materials are monitored by two ${ }^{3} \mathrm{He}$ proportional counters in the sample chamber. The count rate in this $3 \mathrm{He}$ flux monitor is used to determine an empirical correction which is applied to the coincidence count rate.

The plastic scintillators are very sensitive to gamma rays-an effect which can either aid or hinder the assay, depending on the sample characteristics. Lightly shielded scintillators will respond to coincident fission gamma rays which will increase detection sensitivity-a desirable effect. However, these gamma rays will also be attenuated in high- $Z$ matrices and by the uranium in high uranium content samples, which are undesirable effects. The LASL design effort has been generally aimed at reducing the gamma-ray sensitivity, with the penalty of some reduction in detection sensitivity. The scintillators in the $Y-12$ unit are shielded by $5 \mathrm{~cm}$ of lead, which will reduce the accidental coincidence rate of passive gamma rays from the sample and the ${ }^{241} \mathrm{Am}$ Li sources. Further, rejection of prompt coincident gamma rays is accomplished electronically by time-of-flight (TOF) discrimination. Coincident gamma rays have flight times from sample to scintillator of $<2$ nsec. These are rejected by using a coincidence window that counts only events separated by 6 to $46 \mathrm{nsec}$. This also helps in the assay of uranium that contains variable amounts of $232 \mathrm{U}$. The troublesome coincident gamma rays from the $203 \mathrm{TI}$ daughter of $232 U$ are rejected by the TOF discrimination. 
Succeeding versions of the random driver have become more automated under computer control. A digital-readout load cell verifies the sample's gross weight. Thermistor temperature sensors are read by the computer, and software corrections are applied for temperature-dependent count rates. Least-squares fitting routines are available to generate calibration parameters. Data reduction with complete error propagation is carried out quickly. 


\section{DESCRIPTION OF THE LASL/DOE RANDOM DRIVER AT Y-12}

\section{HARDWARE}

The random driver under evaluation at $\mathrm{Y}-12$ is pictured in Figure 2. The unit consists of the following components (as shown in Figure 2 from right to left): a sample assay chamber and detector unit; an electronics rack containing data acquisition, control, and processing electronics; a printer; and a video terminal.

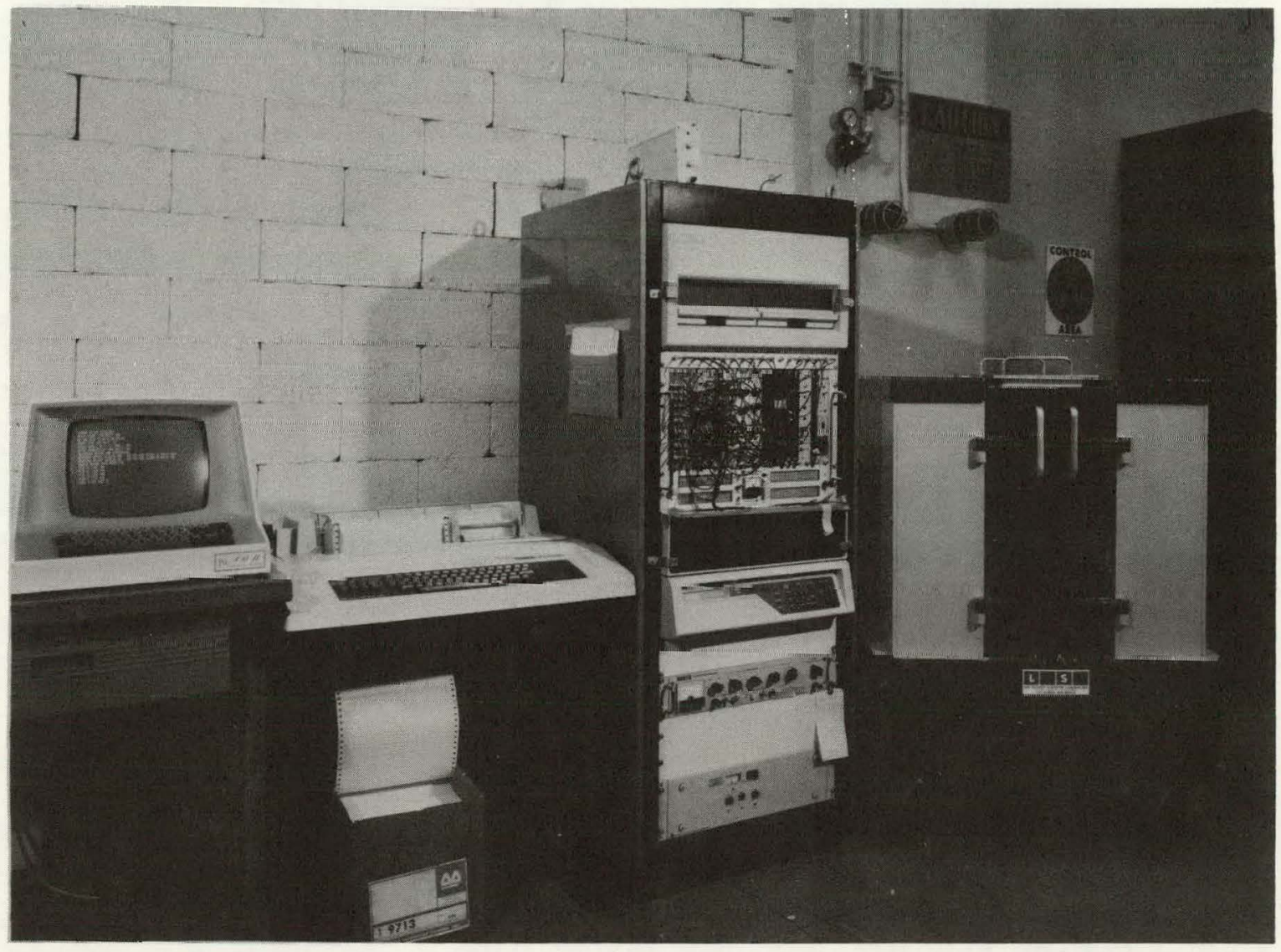

175664

Figure 2. THE LASL/DOE RANDOM DRIVER UNDER EVALUATION AT Y-12.

The sample assay chamber and detectors are shown schematically in Figure 3. The detectors are 50 -mm-thick by $250-\mathrm{mm}$-wide by $610-\mathrm{mm}$-high rectangular slabs of Pilot $\mathrm{F}$ plastic scintillator material. The $50-\mathrm{mm}$ by $250-\mathrm{mm}$ edge is viewed from the bottom by two Amperex XP-2230 photomultiplier tubes (PMT) mounted in ORTEC Model 265 PMT bases. The sample sits on a turntable which rotates at a rate of about $6 \mathrm{rpm}$ to smooth out the effects of radial flux and concentration variations. The thermal flux in the assay chamber is monitored by two $200-\mathrm{mm}$-long by $25-\mathrm{mm}$-diameter $3 \mathrm{He}$ tubes filled to $600 \mathrm{kPa}(6 \mathrm{~atm})$. The boral lining of the assay chamber reduces the thermal flux in the chamber and helps to 


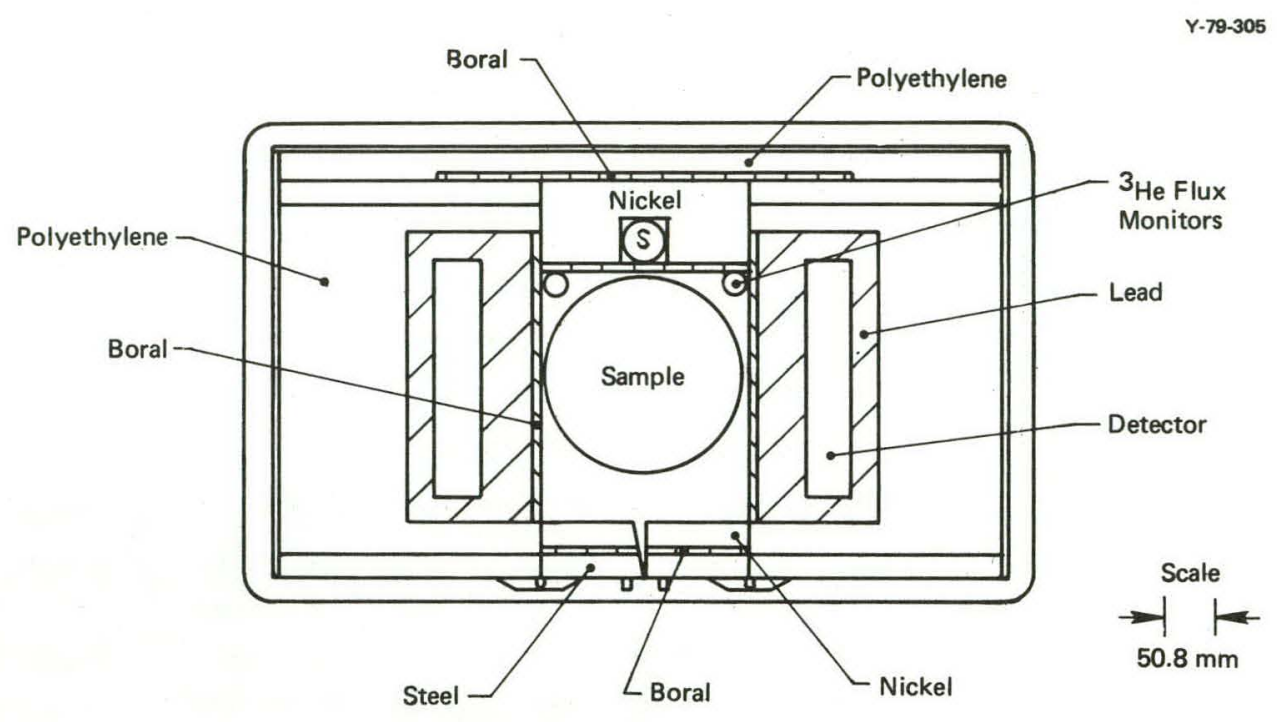

Figure 3. TOP VIEW OF THE RANDOM DRIVER.

preserve a fast interrogating spectrum. The interrogating sources are two ${ }^{241} \mathrm{Am}$ Li $(\alpha, \mathrm{n})$ sources with a vertical center-to-center spacing of $420 \mathrm{~mm}$. The lower source is $100 \mathrm{~mm}$ below the plane of the sample turntable. Each source contains about 10 curies of $241 \mathrm{Am}$, giving a neutron output of about $5.7 \times 10^{5}$ neutrons/sec for each source.

A load cell is used to check the gross weight of the sample on the turntable, and four thermistor temperature sensors can be placed to monitor temperatures of interest.

\section{ELECTRONICS}

Data acquisition is accomplished with combined nuclear instrument modules (NIM) and computer automated measurement and control (CAMAC) modules housed in a CAMAC crate. Conventional fast coincidence electronics are used for coincidence counting from the plastic scintillators (Figure 4). The pulse widths and delays are set for a coincidence window extending from 6 to 46 nsec. A detailed alignment procedure for the fast electronics was supplied by LASL. This alignment procedure requires a time-to-amplitude converter, delay unit, and a multichannel analyzer in addition to the electronics supplied with the random driver. This procedure should be followed after major component (eg, PMT) changes or major changes in operating conditions (eg, large high-voltage adjustment).

A block diagram of the $3 \mathrm{He}$ flux monitor is shown in Figure 5 . The relatively fast time constant of $0.8 \mu \mathrm{sec}$ is used to clip the slower rise-time pulses from gamma-ray interactions in the ${ }^{3}$ He tubes. This provides improved gamma-ray discrimination.

All information received from the scintillators, flux monitor, load cell, and temperature sensors is transmitted to a PDP-11/04 minicomputer via a CAMAC crate. This system is indicated schematically in Figure 6. 
Y.79-306

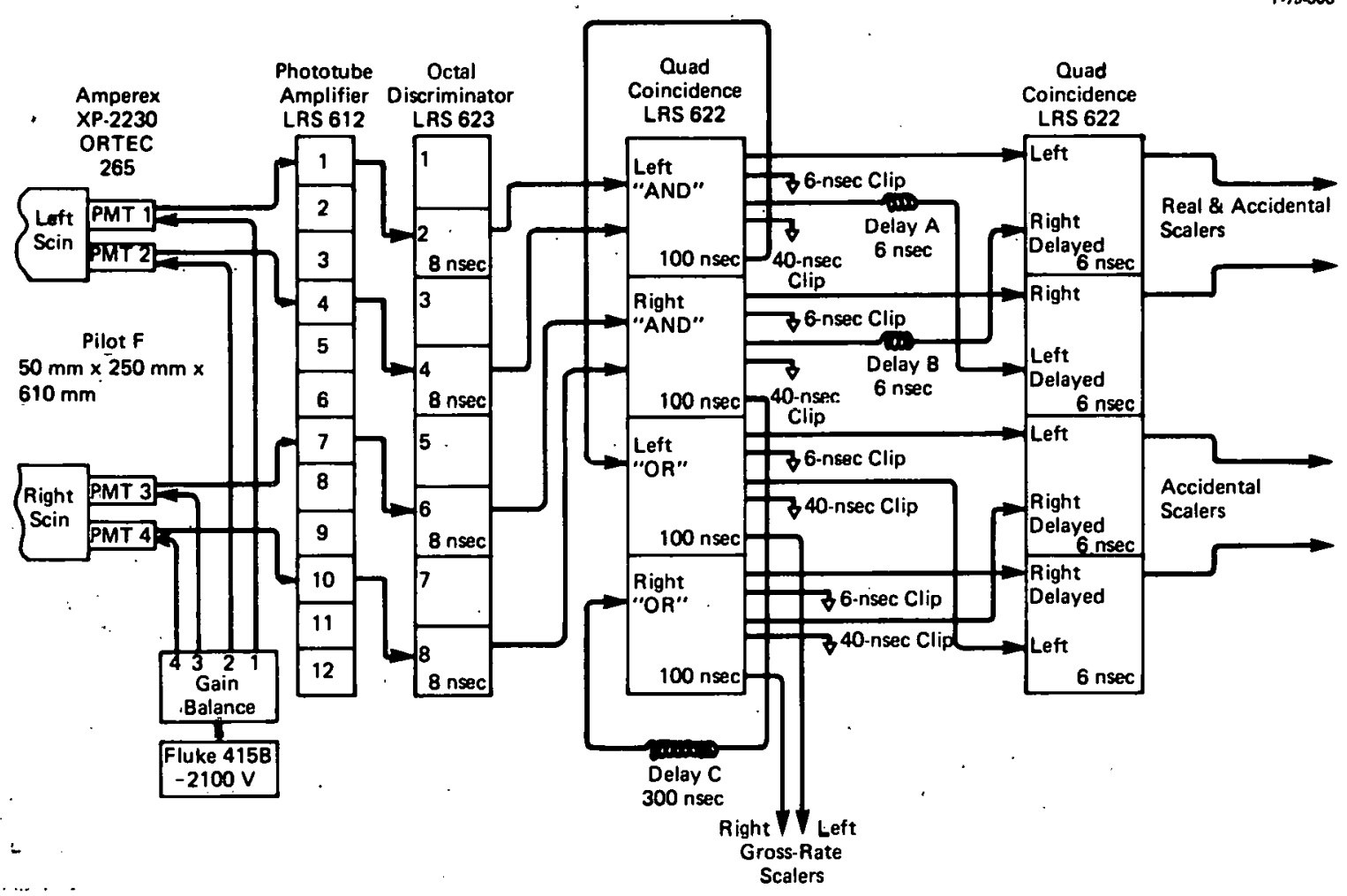

Figure 4. BLOCK DIAGRAM OF FAST COINCIDENCE ELECTRONICS FOR THE RANDOM DRIVER.

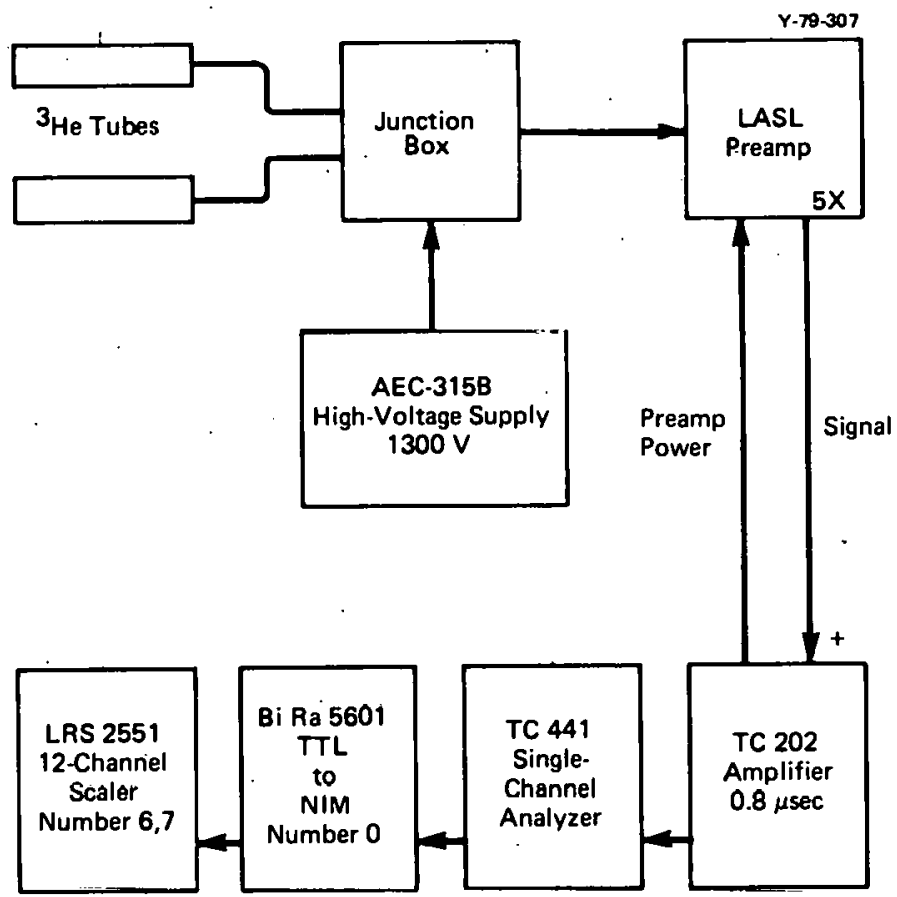

Figure 5. BLOCK DIAGRAM 'OF ELECTRONICS FOR ${ }^{3} \mathrm{He}$ NEUTRON FLUX MONITOR FOR THE RANDOM DRIVER. 


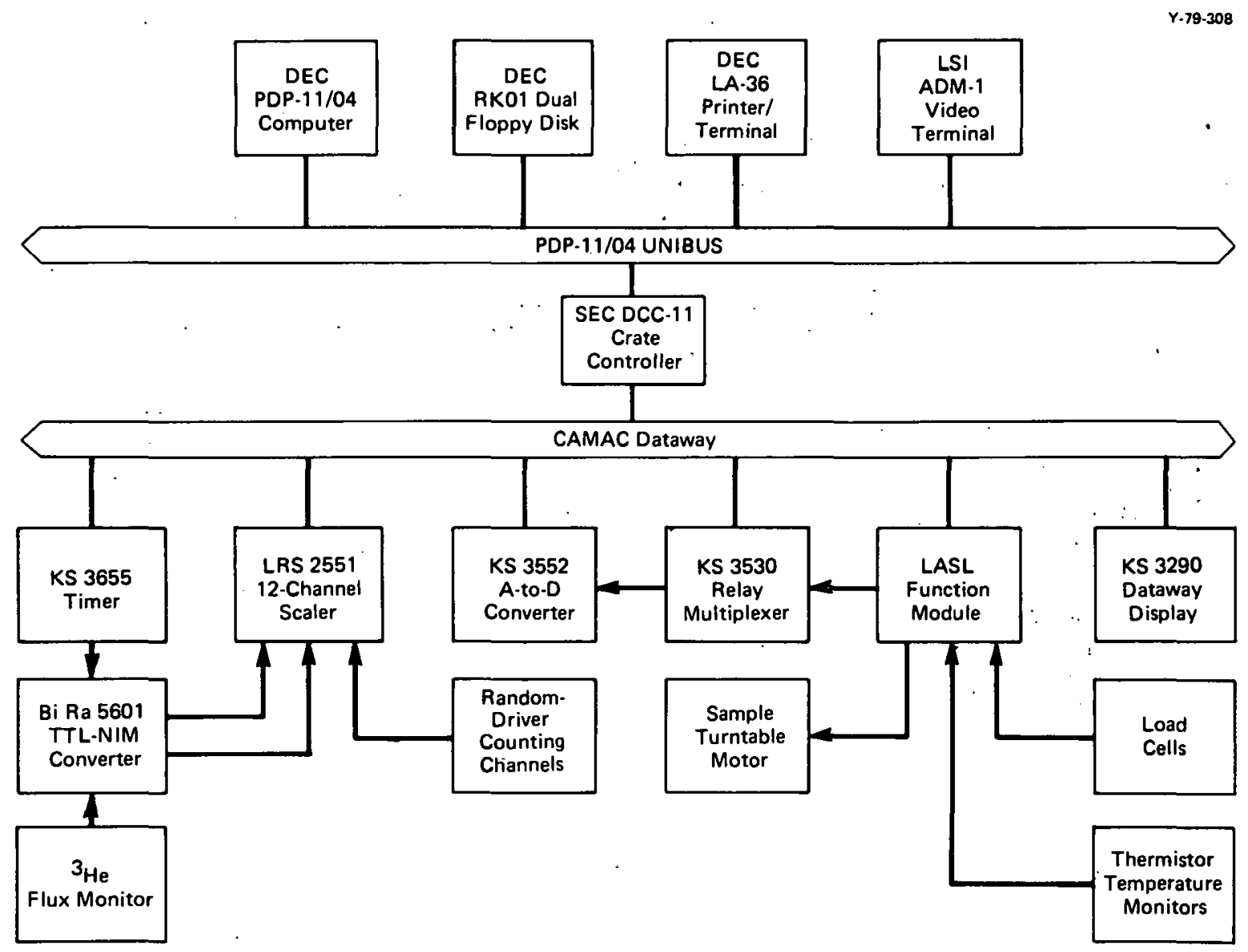

Figure 6. BLOCK DIAGRAM OF PDP-11/04 COMPUTER AND CAMAC DATA ACQUISITION SYSTEM FOR THE RANDOM DRIVER.

\section{SOFTWARE}

The software operating system for the PDP-11/04 is RT-11 Multiuser BASIC. All systems, programs, random-driver programs, and utility routines are stored on one of the two available floppy-disk units. The other floppy disk is used for data storage. Fifty parameters from each run are stored, giving a disk capacity of 300 runs.

The random driver is operated with three overlaid routines, a main control program, a data accumulation routine, and a data reduction routine. Several utility programs are also available to the user. The most important of these allows the user to generate weighted least-squares fits to calibration standards for the generation of calibration parameters and associated errors. Editing routines also allow the user to resequence or delete blocks of BASIC statements.

The scope of the data accumulation and reduction program can be better understood by considering the 50 parameters that are stored for each run. These are listed in Table 1. 
Table 1

RANDOM DRIVER PARAMETERS STORED FOR EACH SAMPLE

\begin{tabular}{|c|c|}
\hline Parameters & Comment \\
\hline 1. Run Number & Sequentially assigned $1-300$ \\
\hline 2. Material Type & $1-5$, Input \\
\hline 3. Gross Weight & Input \\
\hline 4. Net Weight & Input \\
\hline 5. Measured Gross Weight & From load cell for weight check \\
\hline 6. Diameter of Sample & Input for density calculation \\
\hline 7. Fill Height of Sample Can & Input for density calculation \\
\hline 8. Volume of Sample & Calculated \\
\hline 9. Sample Density & Calculated \\
\hline 10. Uranium Density & Calculated \\
\hline 11. Standard Uranium Content (tag) Value & Input for calibration standard \\
\hline 12. Tag Error & Input \\
\hline 13. Enrichment & Input \\
\hline 14. Room Temperature & Measured from temperature sensors \\
\hline 15. Crate Temperature & Measured from temperature sensors \\
\hline 16. PMT Temperature & Measured from temperature sensors \\
\hline 17. High-Voltage Power Supply Temperature & Measured from temperature sensors \\
\hline 18. Count Time & Input \\
\hline 19. Actual Time & Measured \\
\hline 20. Lefi Scintillator Total Coincidence Rate & Messured \\
\hline 21. Right Scintillator Total Coincidence Rate & Measured \\
\hline 22. Left Total Coincidence Rate & Measured \\
\hline 23. Right Total Coincidence Rate & Measured \\
\hline 24. Left Accidental Coincidence Rate & Measured \\
\hline 25. Right Accidental Coincidence Rate & Measured \\
\hline 26. Real Coincidence Rate & Calculated \\
\hline 27. Errór & Calculated \\
\hline 28. Temperature Correction & Calculated \\
\hline 29. Error & Calculated \\
\hline 30. Temperature Corrected Real Coincidence Rate & Calculated \\
\hline 31. Error & Calculated \\
\hline 32. Temperature Corrected Background & From previous background run \\
\hline 33. Error & From previous background run \\
\hline 34. Net Temperature Corrected Real Coincidence & Calculated \\
\hline 35. Error & Calculated \\
\hline 36. ${ }^{3} \mathrm{He}$ Flux Monitor Rate & Measured \\
\hline 37. Error & Calculated \\
\hline 38. Flux Ratio & Calculated \\
\hline 39. Error & Calculated \\
\hline 40. Flux Correction & Calculated \\
\hline 41. Error & Calculated \\
\hline 12. Density Correction & Calculated \\
\hline 43. Error & Calculated \\
\hline 44. Corrected Coincidence Rate & Calculated \\
\hline 45. Error & Calculated \\
\hline 46. Uranium Assay & Calculated \\
\hline 47. Error & Cálculated \\
\hline 48. Calibration Parameter A & From previous calibration run \\
\hline 49. Error & From previous calibration run \\
\hline 50. Calibration Parameter B & From previous calibration run \\
\hline
\end{tabular}




\section{OPERATING HISTORY}

The random driver was delivered to $Y-12$ in June of 1977. Los Alamos Scientific Laboratory personnel spent three days setting up the unit and instructing $Y-12$ personnel in its operation. The unit was operated in Building 9203 initially, with preliminary data accumulated on uranium metal machine turnings. In October of 1977, the unit was moved to Building 9212 where measurements on $\mathrm{U}_{3} \mathrm{O}_{8}$ skull oxide and unleached incinerator ash were carried out.

In January of 1978, project personnel were changed, and a month or so was spent on "relearning" the system. During most of March, April, and into May, the system was down for repairs on the CAMAC power supply. From mid-May through mid-October 1978, the system operated without incident, and evaluation data on the assay of skull oxide and unleached solids were obtained.

The random driver is a complex instrument that has the potential for being a maintenance problem. However, the system is completely modular, and many problems (when recognized) can be repaired by replacing the malfunctioning module. This minimizes system downtime but does require that spare modules be available.

In Table 2 are listed maintenance "incidents" over the past year. Although there have been a significant number of problems, only the CAMAC power supply and floppy-disk problems seriously affected operation. These two problems resulted in major periods of downtime, which are unacceptable in a production environment.

Table 2

RANDOM DRIVER MAINTENANCE

\begin{tabular}{|c|c|c|}
\hline Problem & Approximate Downtime & Repair Method \\
\hline Coincidence Unit & None & Replaced Module \\
\hline DEC Writer & 3Days & Y-12 Electrical Maintenance \\
\hline Video Display & 1 1/2 Weeks & Y-12 Electrical Maintenance \\
\hline PMT High-Voltage Power Supply & 1 Day & Replaced Module \\
\hline Temperature Sensors $(1)$ & None (1 day for recalibration) & Replaced Sensors \\
\hline Load Cell ${ }^{(1)}$ & 2 Days & LASL Personnel \\
\hline NIM-CAMAC Adapter & None & Replaced with Spare \\
\hline CAMAC Power Supply & 10 Weeks & Y-12 Electrical Maintenance \\
\hline Floppy-Disk Drive & 5 Weeks & $\begin{array}{l}\text { Y-12 Electrical Maintenance/ } \\
\text { Manufacturer }\end{array}$ \\
\hline
\end{tabular}

(1) Not essential for system operation.

To minimize maintenance problems, spare modules and parts should be available, and a good working relationship with the electrical maintenance organization needs to be maintained. The performance of the random driver must also be closely monitored by people knowledgeable in its operational characteristics. 


\section{MEASUREMENTS WITH THE RANDOM DRIVER}

\section{$\mathrm{U}_{3} \mathrm{O}_{8}$ SKULL OXIDE}

\section{Material}

Skull oxide is a residue of the uranium casting process. It is formed from residual uranium left in the graphite crucible after casting. This material is collected and burned to $\mathrm{U}_{3} \mathrm{O}_{8}$. Before counting in the random driver, the material is screened through a 30-mesh sieve. The $\mathrm{U}_{3} \mathrm{O}_{8}$ skull oxide that was used in these evaluations contained 70 to $84 \%$ uranium (thenretical is $84.6 \%$ ). The main impurities were carbon from the crucible and zirconium from the mold liner. All skull oxide counted was enriched to a nominal $93.15 \%{ }^{235} \mathrm{U}$.

\section{Container}

The skull oxide is contained in a tall hospital can or "green-salt can" with nominal dimensions of $148 \mathrm{~mm}$ in diameter by $303 \mathrm{~mm}$ high. This can is pictured on the right in Figure 7. The majority of the skull oxide cans are filled to heights of 120 to $230 \mathrm{~mm}$, with a total uranium content in the range of 7 to $10 \mathrm{~kg}$.

\section{Standards}

Early in the program, a set of ten $\mathrm{U}_{3} \mathrm{O}_{8}$ standards was made up from available material. The total uranium content of the standards ranged from about 1 to $12 \mathrm{~kg}$ in approximately $1-\mathrm{kg}$ increments. Carbon dust was added to all standards before the final blending and sampling to ensure that all sample containers were completely filled. This produced a set of standards with a constant fill height and varying uranium concentration. The constant fill height reduced the uncertainty from any possible variation with fill height, although this was expected to be small. Measurements at $\mathrm{Y}-12$, to be discussed later, indicate that fill heights of up to $310 \mathrm{~mm}$ do not affect the response.

The ten standards were reblended and

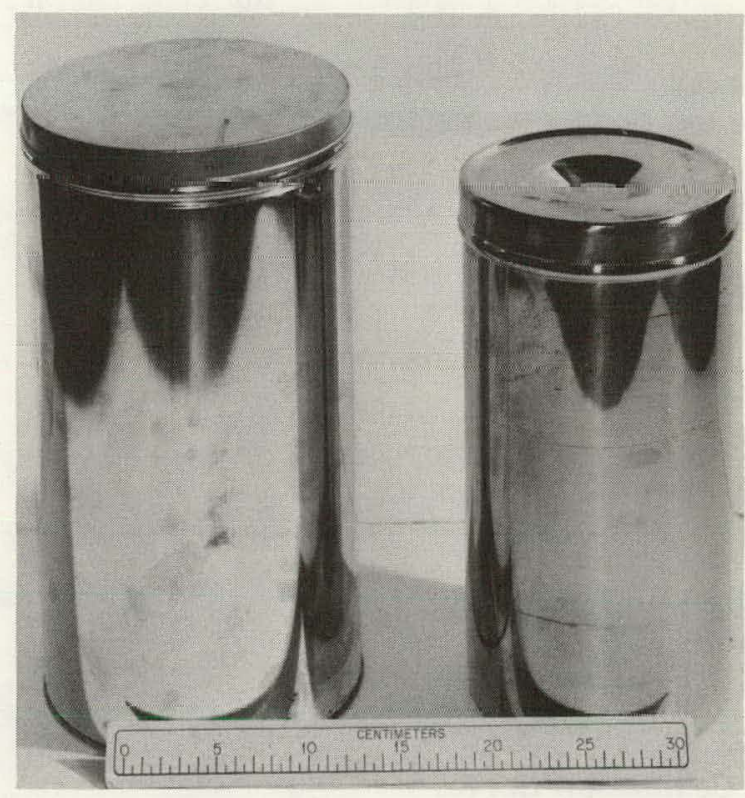

185131

Figure 7. CONTAINERS FOR PROCESS RESIDUES. (The tall hospital can used for $\mathrm{U}_{3} \mathrm{O}_{8}$ is on the right, and the residue can for unleached solids is on the left.) resampled in April 1978 (several months after they were made up), and the new concentration values were compared with the original values. A relative standard deviation of $0.8 \%$ on an individual measurement was derived from this analysis. For interim work, an uncertainty of $1 \%$ at the 10 level was 
assigned to the concentration of the standards. This uncertainty arises from blending, sampling, and chemical analysis errors. Experience indicates that the blending and sampling errors dominate the total uncertainty for this impure oxide material.

In October 1978, the standards were again blended, sampled, and analyzed. This time extra care was taken to ensure representative sampling, and three samples were taken from different regions of each standard. Each of the three samples was analyzed on a different day. The three uranium concentration values $(\mathrm{g} \mathrm{U} / \mathrm{g})$ for each standard were in good agreement with each other and with the April sampling. The data are summarized in Table 3. A pooled $\sigma_{\text {mean }}$ of $0.00128 \mathrm{~g} \mathrm{U} / \mathrm{g}$ was calculated from the standard deviations of each standard listed in Table 3. Percent uncertainties at the $1 \sigma$ level ranged from less than 0.2 to $0.7 \%$. These more precise concentration values are to be used for future work with these standards.

Table 3

CHEMICAL ANALYSIS OF $\mathrm{U}_{3} \mathrm{O}_{8}$ SKULL OXIDE STANDARDS

\begin{tabular}{clcccccc}
\hline & \multicolumn{7}{c}{ Uranium Concentration (g U/g) } \\
\cline { 2 - 6 } $\begin{array}{c}\text { Standard } \\
\text { Number }\end{array}$ & $\begin{array}{c}\text { Original } \\
(4 / 78)\end{array}$ & $\begin{array}{c}\mathrm{A} \\
(10 / 78)\end{array}$ & $\begin{array}{c}\mathrm{B} \\
(10 / 78)\end{array}$ & $\begin{array}{c}\mathrm{C} \\
(10 / 78)\end{array}$ & Mean & $\sigma_{\text {mean }}{ }^{(1)}$ & $\begin{array}{c}\text { Percent } \\
\text { Error (2) }\end{array}$ \\
\hline 1 & 0.17929 & 0.1829 & 0.1836 & 0.1802 & 0.18150 & 0.00104 & 0.70 \\
2 & 0.30616 & 0.3112 & 0.3091 & 0.3098 & 0.30906 & 0.00106 & 0.41 \\
3 & 0.34755 & 0.3555 & 0.3527 & 0.3533 & 0.35226 & 0.00168 & 0.36 \\
4 & 0.47193 & 0.4749 & 0.4769 & 0.4746 & 0.47458 & 0.00102 & 0.27 \\
5 & 0.58320 & 0.5907 & 0.5878 & 0.5837 & 0.58635 & 0.00178 & 0.22 \\
6 & 0.57810 & 0.5760 & 0.5752 & 0.5729 & 0.57555 & 0.00108 & 0.22 \\
7 & 0.68980 & 0.6957 & 0.6913 & 0.6911 & 0.69198 & 0.00128 & 0.18 \\
8 & 0.7225 & 0.7232 & 0.7258 & 0.7208 & 0.72308 & 0.00104 & 0.18 \\
9 & 0.7609 & 0.7566 & 0.7582 & 0.7526 & 0.75708 & 0.00174 & 0.17 \\
10 & 0.75505 & 0.7538 & 0.7554 & 0.7540 & 0.75456 & 0.00039 & 0.17 \\
\hline
\end{tabular}

(1) $\sigma_{\text {mean }}($ pooled $)=0.00128$.

(2) $\sigma_{\text {mean }}($ pooled) $/$ mean $\times 100 \%$.

\section{Calibration Curves}

Numerous calibration data using all ten standards were taken during the initial phases of the evaluation. Data for Standards 1 - 9 were fit very well with a linear function of count rate versus uranium mass, as shown in Figure 8. However, Standard 10, at about $11.7 \mathrm{~kg}$, consistently fell above the curve and was dropped from the calibrations. The results of these calibrations indicate a linear random driver response from below $1 \mathrm{~kg}$ to above $10 \mathrm{~kg}$ of uranium with a small positive intercept in the range of 1 to 4 counts/sec. 


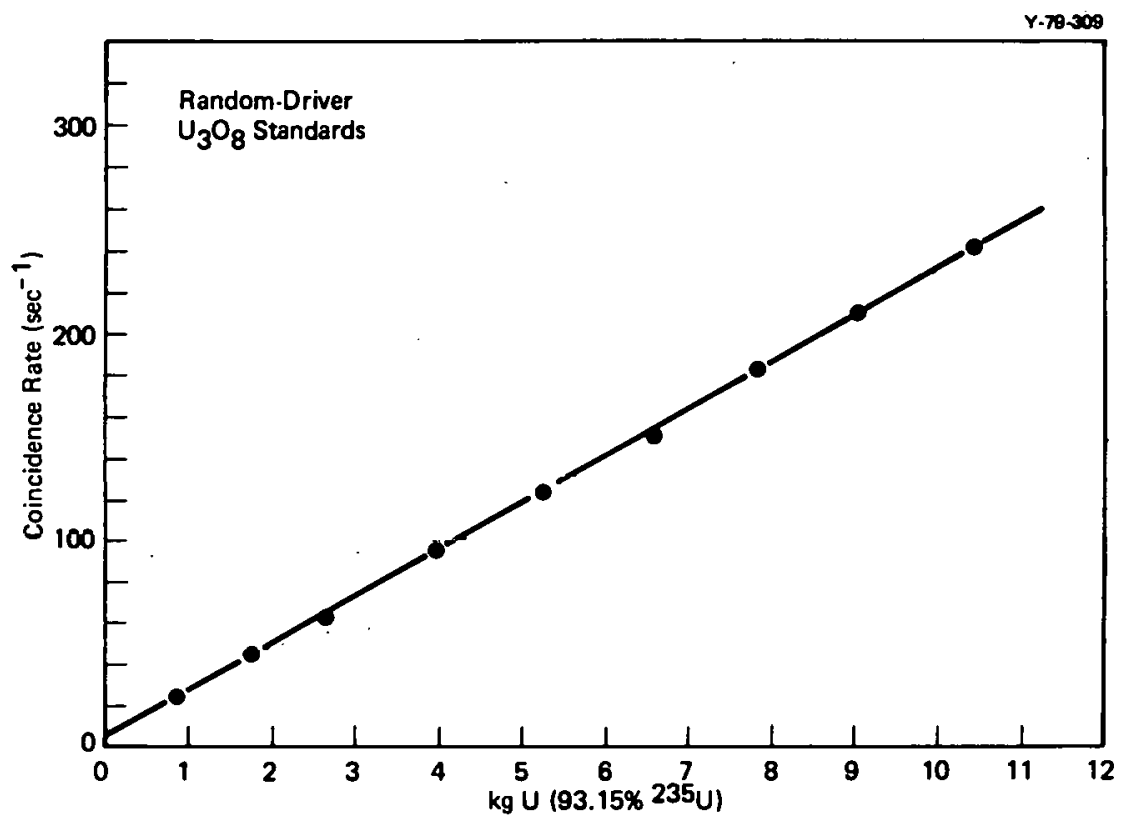

Figure 8. TYPICAL CALIBRATION CURVE FOR THE RANDOM DRIVER WITH $\mathrm{U}_{3} \mathrm{O}_{8}$ SKULL OXIDE STANDARDS.

Many of LASL's reported results 10,12,13,18 indicate a somewhat nonlinear response curve below $4 \mathrm{~kg}$ of uranium. Their response fits the form:

$$
\text { Response }(R)=\frac{a M}{(1+b M)}
$$

where $M$ is the uranium mass and $a$ and $b$ are constants. The $Y-12$ response may well follow this form, but it has not been examined closely in the 0 to $4-\mathrm{kg}$ region because most of the $\mathrm{U}_{3} \mathrm{O}_{8}$ samples at $\mathrm{Y}-12$ are in the 7 to $9-\mathrm{kg}$ range. A straight-line fit to data that actually followed the $a M /(1+b M)$ form would yield a positive intercept. Indeed, other reported LASL data that have been fit lincarly exhibit a positive intercept. 16

A calibration curve whose slope increased with increasing mass [negative $b$ in the form $R=$ $a M /(1+b M)]$ might be expected because of multiplication in the sample. It is probably a fortuitous result of attenuation, multiplication, and container geometry that the $\mathrm{Y}-12$ calibration curves for skull oxide show linearity up to such a high mass.

\section{Vertical Response}

Los Alamos Scientific Laboratory measurements ${ }^{13}$ on a 1975 version of the random driver having the same geometry as that of the unit at $\mathrm{Y}-12$ indicated a vertical response profile that was flat to within $1 \%$ over a range of 50 to $350 \mathrm{~mm}$ above the sample table. It was deemed advisable to repeat these measurements with the $Y-12$ instrument. $A$ 
152-mm-diameter by 3.18-mm-thick disk containing 1107 grams of uranium $(93.15 \% 235 \mathrm{U})$ was fabricated, and a series of measurements was taken with the random driver for various positions of the disk within the sample cavity.

The results shown in Figure 9 indicate a flat differential response from 0 to $310 \mathrm{~mm}$. An averaged response for a typical sample volume was calculated from these data. This is also plotted in Figure 9 versus vertical position of the sample volume inside the random driver cavity. The volume-averaged response is flat to within $\pm 1 \%$ from 0 to $310 \mathrm{~mm}$. It is not

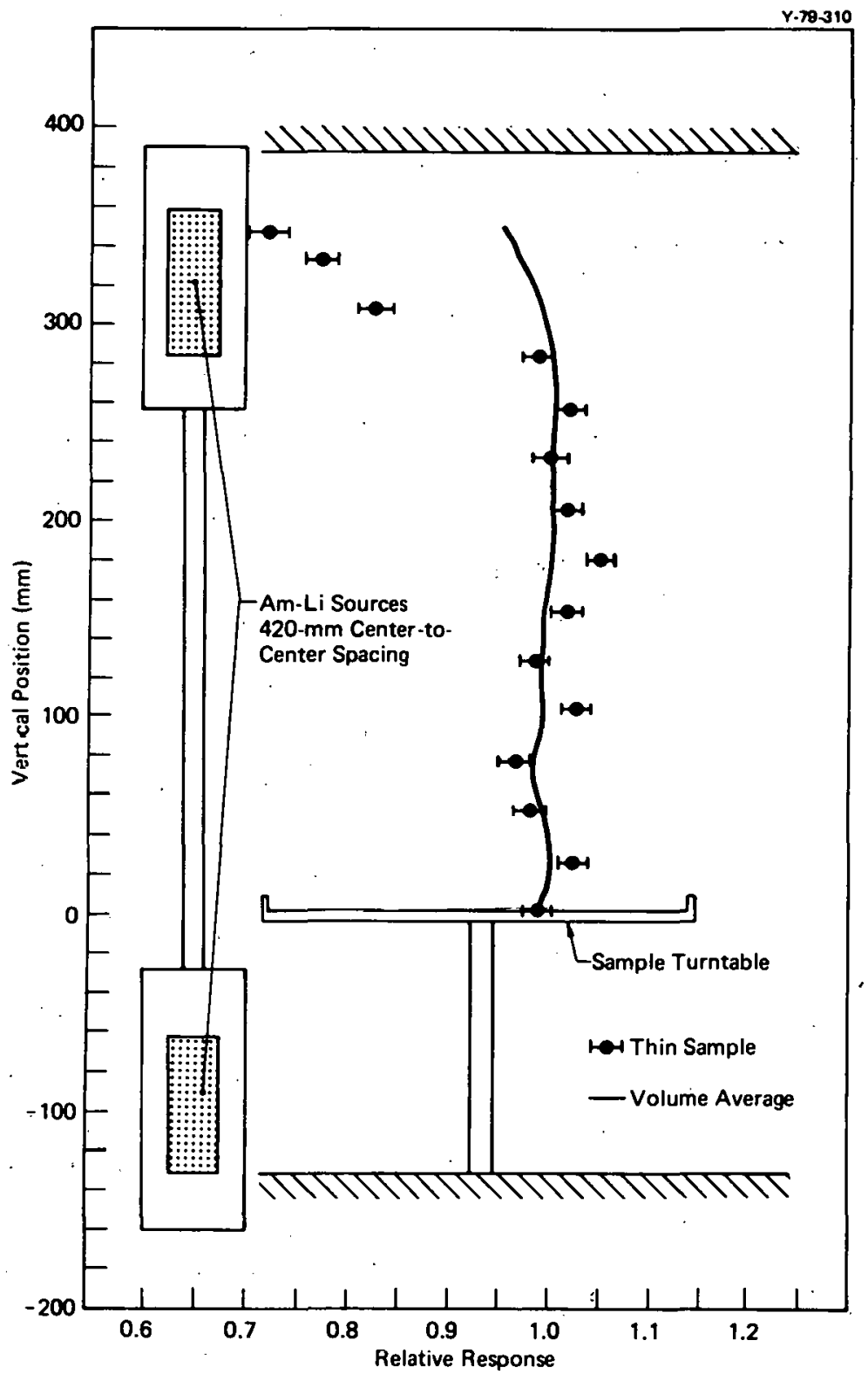

Figure 9, VERTICAL RESPONSE PROFILE OF THE LASL/DOE RANDOM DRIVER UNDER EVALUATION AT Y $Y$-12. (Volume-averaged response is flat to within $\pm 1 \%$ from 0 to $310 \mathrm{~mm}$.) 
clear that the flat volume-averaged response will apply to real samples because of attenuation and absorption within the sample. Nevertheless, these data indicate that the interrogating flux is quite uniform. No corrections are made for sample-height variation. Symmetry about the mid-plane between the Am Li sources would indicate that this flat interrogating flux could be achieved over a total height of about $380 \mathrm{~mm}$; however, to achieve this, the sample turntable would have to be lowered. There appears to be no need to take advantage of this increased flat response range at this time.

\section{Temperature Coefficient}

The temperature sensitivity of the PMTs and the nature of the pulse-height spectrum from plastic scintillators make the random driver inherently temperature sensitive. Gain stabilization is impractical for plastic scintillators; thus, a measured temperature correction is used to correct the coincidence count rate for temperature changes. A thermistor placed on the PMT base is used for this correction. Temperature effects are expected to depend on the specific electronics (PMTs, amplifiers, high-voltage power supplies, and discriminators) and operating conditions and cannot be predicted from previous experience. An early version 13 of the $\mathrm{Y}-12$ instrument evaluated at the Savannah River Plant exhibited a temperature coefficient of $+0.66 \% /{ }^{\circ} \mathrm{C}$, while the $\mathrm{Y}-12$ instrument vielded a coefficient of $-0.14 \% /{ }^{\circ} \mathrm{C}$ during tests at LASL. At $\mathrm{Y}-12$, the curve of coincidence rate versus temperature data shown in Figure 10 yielded a temperature coefficient of $-1 \% /{ }^{\circ} \mathrm{C}$. This value is currently being used in the software-applied temperature correction and should be reevaluated after component changes.

\section{Instrument Instability}

The temperature-coefficient correction discussed above attempts to correct for instrument instabilities caused by variations in the ambient temperature. This correction is only partially successful in the sense that the instrument still exhibits count-rate drifts that cannot be fully explained by temperature effects. These drifts seem to be random in nature and have little effect on long-term random driver totals. However, the short-term precision of the rendom driver is limited by these effects to about $3 \%$ at the $1 \sigma$ level.

During a lengthy series of measurements on skull oxide (to be discussed later), the slope of the calibration curve was updated after every third sample by counting a single $7801 \mathrm{~g} \mathrm{U}$ calibration standard. The intercept of the calibration curve was assumed to remain constant. The random driver measurement of the standard (before calibration updating) was recorded using a calibration constant from the previous calibration update. A total of 38 standard runs were recorded over a 10-day period.

The statistics of these assays are presented in Table 4 . Table 4 shows that the long-term accuracy, [(measurement mean - standard value)/standard value] $\times 100$, is good (on the order of $0.1 \%)$ because of the frequent calibration updates. However, the precision of a single measurement of the standard is about 3.0\% ( $1 \sigma$ level). This is much worse than that predicted from counting statistics alone. The cause of this instability is unknown but is not 
unexpected with a phototube/plastic scintillator system in an uncontrolled environment. Other random drivers in use at LASL exhibit similar characteristics. 20

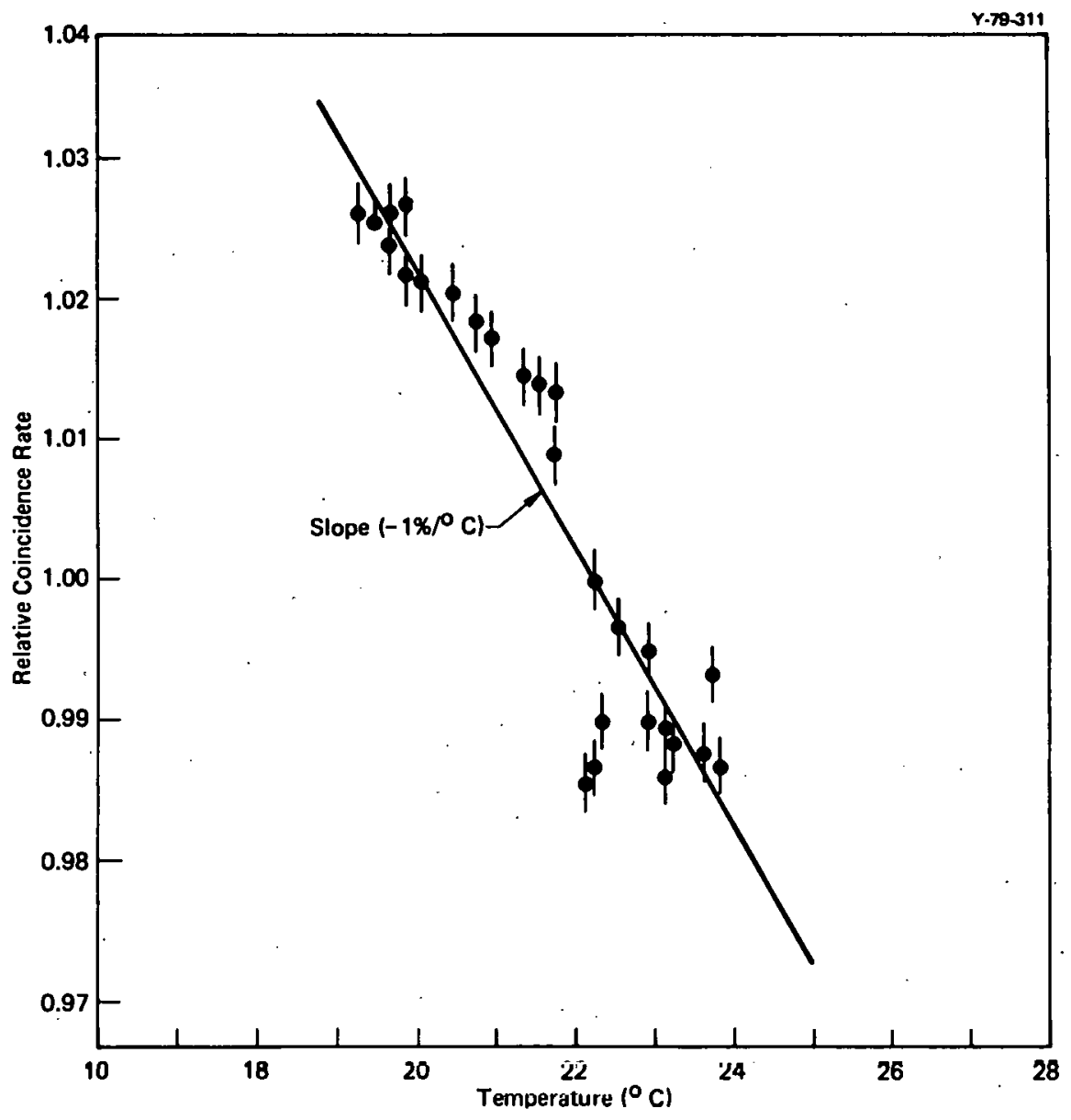

Figure 10. TEMPERATURE CORRECTION DATA FOR THE RANDOM DRIVER.

Table 4

REPEATED ASSAY OF 7801-g U STANDARD

Expected Statistical Assay Precision for 300-sec Run.

Including 1\% Uncertainty in Calibration Standard

$0.7 \%$

Statistical Uncertainty in Coincidence Count Rate for

010

Assigned Value of Calibration Standard

$7801.0 \mathrm{~g}$

Mean Value of 38 Random Driver Measurements of

$7792.4 \mathrm{~g}$ Calibration Standard

(Mean - Standerd)/Standard $\times 100 \%$

Standard Deviation of Individual Random Driver

$233.7 \mathrm{~g}$

Measurement from Distribution of 38 Measurements 


\section{Precision of the Sampling and Chemical Analysis Results}

The random driver precision of about 3\% (previously discussed) does not compare favorably with chemical analysis precisions which are often on the order of a few tenths of $1 \%$ or better. However, one must consider the combination of sampling and chemical analysis that is routinely performed on the impure oxide material. The sampling errors that arise from the problem of obtaining a representative sample of nonhomogeneous material dominate the total error.

This was illustrated quantitatively by examining three independent routine sampling and chemical analysis results for uranium concentrations on twelve different batches of skull oxide. A relative standard deviation of $3 \%$ was computed by pooling the variances of the twelve samples run in triplicate.

This shows that there is a significant lack of precision in the routine sampling and chemical analysis results on skull oxide. Hence, the precision of the random driver measurements is equivalent to that displayed by routine sampling and chemical analysis techniques.

\section{Measurements on Skull Oxide Inventory}

During August of 1978, an extensive test of the ability of the random driver to accurately measure the uranium content of $\mathrm{U}_{3} \mathrm{O}_{8}$ skull oxide was carried out by counting almost 90 cans of material in groups of from 12 to 15 cans. The total uranium content for all of the cans was about $700 \mathrm{~kg}$ of uranium (tag value), as determined by sampling and chemica! analysis. These measurements provided both a check on the accuracy of the calibration standards and data on the usefulness of the flux and density corrections.

The random driver is very sensitive to low- $Z$ matrix materials in the sample, as has been discussed previously. The ${ }^{3} \mathrm{He}$ flux monitor measures the effect that matrix moderation has on the interrogating flux.

Different empirical results for the flux monitor correction have been used 12,14, 16 with the results of Reference 16 currently in the Y-12 data reduction program. Reference 16 also describes an empirical density correction that is currently in the $Y-12$ software. The work on defining these correction factors was undertaken with the idea of making the random driver measurements matrix insensitive, which would reduce the need for identical standards. There is no reason to expect that the LASL-developed corrections will be suitable for Y-12 materials. We have tried to evaluate their suitability "as is" but have not yet attempted to improve them. Although the philosophy of the $\mathrm{Y}-12$ evaluation is to use identical standards, it is recognized that the $\mathrm{U}_{3} \mathrm{O}_{8}$ standards are not identical to the routine skull oxide material. Thus, an evaluation of the correction factor is appropriate.

The skull oxide samples were counted for $300 \mathrm{sec}$ with a 7801-g U standard counted after every; third sample. Once a week, a linear calibration curve was defined with standards of 
$878,2654,5265,7801$, and 10,411 grams. The intercept defined by this linear curve was fixed, and the slope was updated every time the 7801-gram standard was recounted.

The results of the counting are tabulated in Table 5 and summarized in histogram form in Figure 11. These data show that the bias for the assays using the temperature corrected coincidence rate is about the same as that for the fully corrected coincidence rate but of opposite sign. The systematic error (bias) on these measurements is $<0.5 \%$. There is no significant difference in the magnitude of the bias, regardless of whether the flux and density correction factors are used. Other experience on smaller numbers of samples (not detailed here) favors using the temperature corrected coincidence rate (no flux and density correction). This choice has not been definitely established to date and should be investigated further. A plot of random driver assay versus Tag values in Figure 12 does not show any systematic bias as a function of sample mass.

Table 5

COMPARISONS OF URANIUM CONTENT IN U $\mathrm{U}_{3} \mathrm{O}_{8}$ SKULL OXIDE SAMPLES USING RANDOM-DRIVER ASSAY RESULTS AND TAG VALUES

\begin{tabular}{|c|c|c|c|c|}
\hline & \multirow[b]{2}{*}{$\begin{array}{c}\text { Number } \\
\text { of } \\
\text { Samples }\end{array}$} & \multirow[b]{2}{*}{$\begin{array}{l}\text { Tag Value } \\
\text { (g U) }\end{array}$} & \multicolumn{2}{|c|}{ Random-Driver Assay Results } \\
\hline & & & $\begin{array}{c}\text { Fully } \\
\text { Corrected } \\
\text { Coincidence } \\
(g \text { U) }\end{array}$ & $\begin{array}{c}\text { Temperature } \\
\text { Corrected } \\
\text { Coincidence } \\
(\mathrm{g} \mathrm{U})\end{array}$ \\
\hline & 15 & 131,010 & 129,624 & 131,426 \\
\hline & 15 & 115,022 & 113,967 & 114,545 \\
\hline & 15 & 126,388 & 126,095 & 127,095 \\
\hline & 14 & 116,135 & 115,795 & 116,545 \\
\hline & 15 & 117,505 & 117,742 & 118,754 \\
\hline & 12 & 96,171 & 96,743 & 96,296 \\
\hline Total & 86 & 702,231 & 699,966 & 704,661 \\
\hline \multicolumn{3}{|c|}{$\begin{array}{l}\text { Percent difference in random driver and } \\
\text { tag measurements total }\end{array}$} & -0.323 & 0.346 \\
\hline \multicolumn{3}{|c|}{$\begin{array}{l}\text { Percent relative standard deviation for } \\
\text { individual samples }\end{array}$} & 2.05 & 2.33 \\
\hline
\end{tabular}

A first analysis of the data in Table 5 indicated eight possible "outliers" whose random driver assay differed from the Tag value by more than $6 \%$. This $6 \%$ deviation, which defines an outlier, is somewhat arbitrary since some measurements with deviations this large are to be expected in a population of this size whose relative standard deviation is believed to be about 3\% ( $1 \sigma$ level). (Table 5 indicates a relative standard deviation on an individual measurement of nearer $2 \%$.) Suspicions arose, however, over these outliers since all random driver assays yielded values that were lower than the Tag values. These values were confirmed by remeasuring five of the eight samples. Sampling errors were suspected, so seven of the eight outliers were carefully resampled. The resampling confirmed the suspicion 


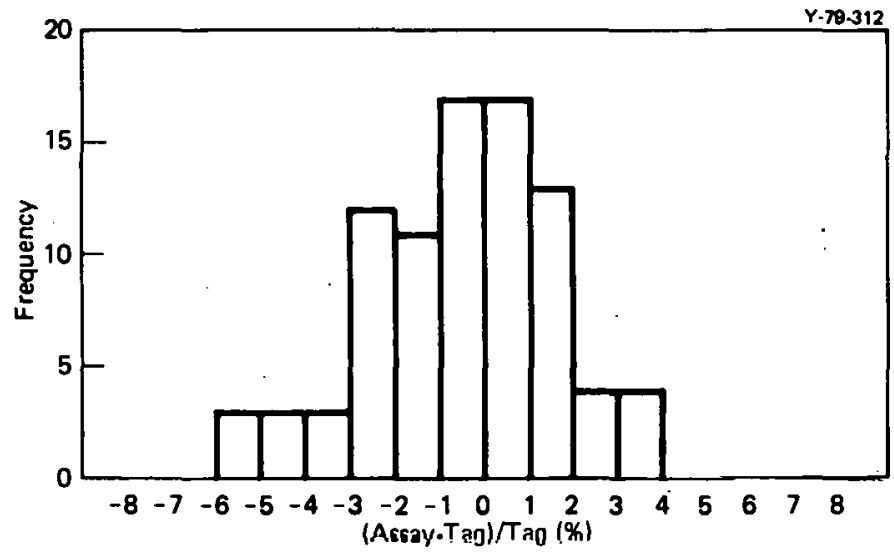

(a) Fully Corrected Coincidence Rate.

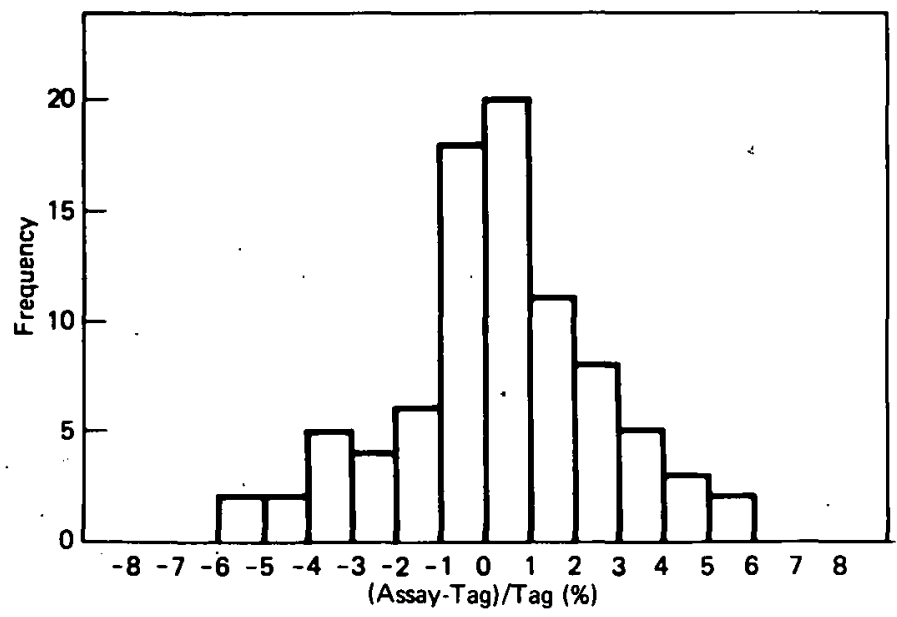

(b) Temperature Corrected Coincidence Rate.

Figure 11. DISTRIBUTION OF THE DEVIATIONS OF THE RANDOM DRIVER ASSAY FROM THE TAG VALUES FOR DATA WITH TEMPERATURE, DENSITY, AND FLUX CORRECTIONS (HISTRFRAM a). AND WITH. TEMPERATURE CORRECTION ONLY (HISTOGRAM b).

of sampling errors in the original Tag values. These results are shown in Table 6 . The original Tag values were in error by almost $5 \mathrm{~kg}$ of uranium for these seven samples. The overall comparisons in Table 5 and Figure 11 have been made with the reanalyzed concentration results for the Tag values of these seven resampled outliers.

Measurements on the skull oxide inventory show that random driver analyses exhibit an accuracy of better than $1 \%$ with a precision in the range of 2 to $3 \%(1 \sigma$ level). Analysis of the precision of sampling and chemical analysis results shows that the random driver yields equivalent results with the advantage of "immediate answers." Immediate answers means that it takes about ten minutes to completely process one can of skull oxide including loading, computer dialog, counting time, data printout, and unloading. Hard-copy 


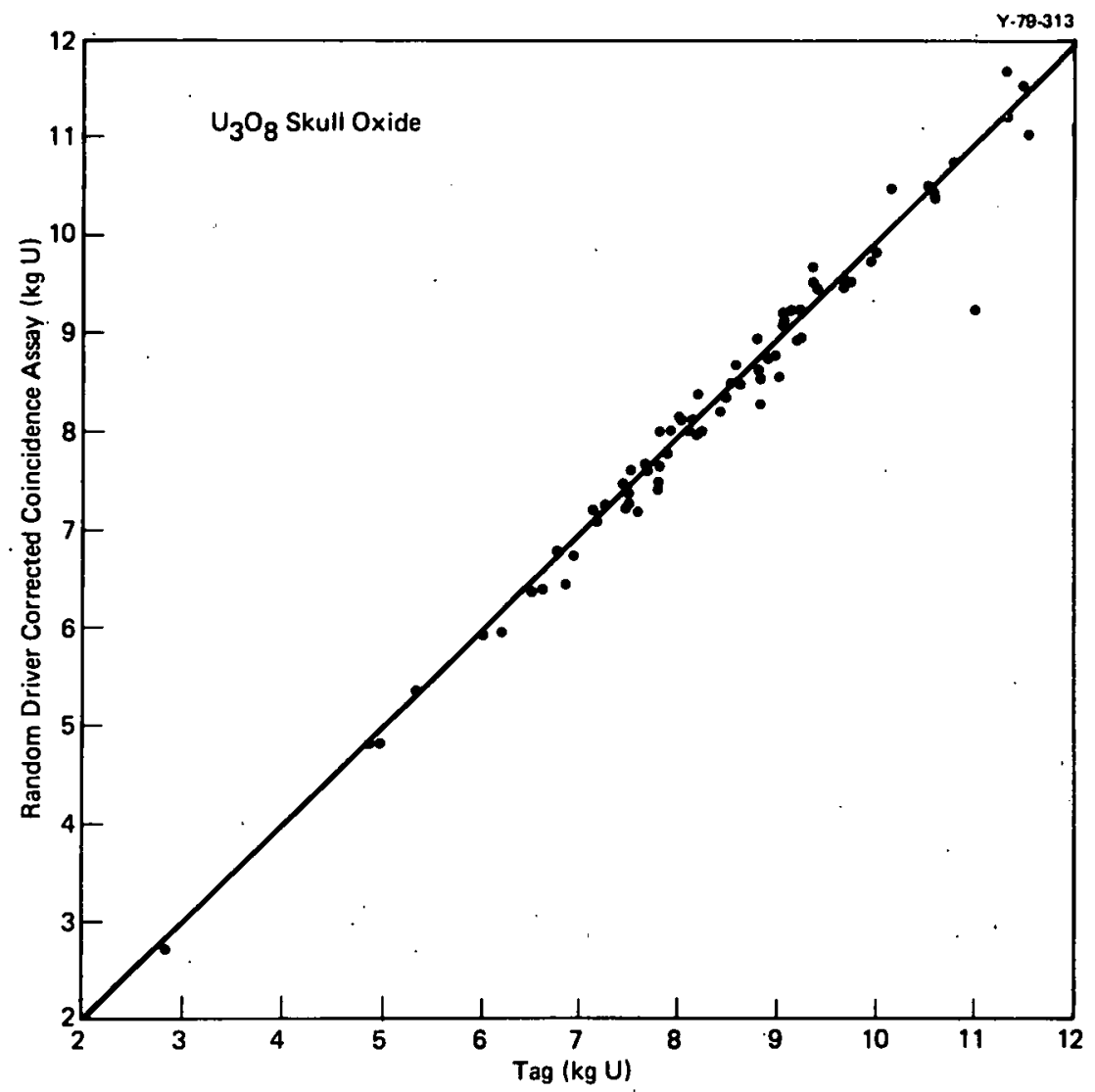

Figure 12. RANDOM DRIVER ASSAY VERSUS TAG VALUES FOR $\mathrm{U}_{3} \mathrm{O}_{8}$ SKULL OXIDE. (Line indicates equal values.)

concentration results are available at the end of the data printout. Allowing for calibration updates, background measurements, and other factors, a throughput of 25 can per shift is not unreasonable.

One important caution must be noted. The random driver actually measures the ${ }^{235} \mathrm{U}$ content, whereas $Y-12$ has to account for total uranium. This requires that the $235 U$ enrichment be available as an input parameter for the random driver dataanalysis program, which implies that some sort of sampling and isotopic analysis has already been performed on the sample. This will take time and manpower, and seems to negate some of the benefits of the random driver. The random driver, however, will provide accurate results on recovered material where the isotopic analysis is already known. Much material falls into this class. Even if the isotopic analysis is not known, a knowledgeable
REANALYSIS OF OUTLIERS

\begin{tabular}{ccc}
\hline $\begin{array}{c}\text { Original } \\
\text { Tag Values } \\
(\mathrm{g} \mathrm{U})\end{array}$ & $\begin{array}{c}\text { Random-Driver Assay } \\
\text { Corrected Coincidence } \\
(\mathrm{g} \mathrm{U})\end{array}$ & $\begin{array}{c}\text { Reanalysis } \\
\text { Tag Values } \\
(\mathrm{g} \mathrm{U})\end{array}$ \\
\hline 8,653 & 7,236 & 7,147 \\
7,882 & 7,121 & 7,127 \\
3,926 & 3,528 & 3,459 \\
6,430 & 5,984 & 5,879 \\
6,699 & 6,223 & 6,177 \\
8,036 & 7,434 & 7,415 \\
7,222 & 6,836 & 6,795 \\
\hline $48,848$. & 44,362 & 43,999 \\
\hline
\end{tabular}


estimate of the $235 U$ isotopic percentage can be used, allowing an immediate estimate of the total uranium to be made with the random driver. Currently, such estimates are not available, and several weeks must pass before the laboratory analysis is available.

\section{UNLEACHED SOLIDS}

\section{Material and Container}

Unleached solids is the term used to describe the incinerator ash left after burning contaminated combustibles. This material is contained in a residue can measuring $178 \mathrm{~mm}$ in diameter by $352 \mathrm{~mm}$ high. This can is pictured on the left in Figure 7.

Typical uranium concentration falls in the range from 2 to $10 \%$ by weight with the majority of samples falling in the 3 to $7 \%$ range. A typical residue can will contain 200 to 400 grams of uranium, with a total net weight of 5 to $6 \mathrm{~kg}$ (cans are filled to a height of 20 to $25 \mathrm{~cm}$ ). The $235 \mathrm{U}$ enrichment varied between 88 and $93 \%$, averaging $90 \%$ for the 24 cans used in these measurements. It is important to note that the $235 \mathrm{U}$ enrichment is not constant, as it was for the skull oxide.

\section{Standards}

No unleached solids "standards", as such, were designated during the measurements on this material type. The counting was monitored using an 878-g $U$ standard of skull oxide with a concentration of $0.1815 \mathrm{~g} \mathrm{U} / \mathrm{g}$. The counting data were examined with two questions in mind. First, were the data self-consistent, and could any samples be chosen that could be used as "secondary standards"? Second, was the 878-g U skull oxide standard a suitable standard for unleached solids, and if so, did the count rate need to be corrected with the flux and density corrections?

\section{Measurements on Unleached Solids}

A total of 24 cans of unleached solids were counted in two groups of 12 . Initially, the cans were counted for $1000 \mathrm{sec}$ each, with the $878 \mathrm{~g} \mathrm{U}$ skull oxide standard used to update the calibration after every third can. The calibration was assumed to be linear with a zero intercept. The linear calibration with a positive intercept that was used for the skull oxide did not work for the unleached solids data. Because only one skull oxide standard was available that had a $\mathrm{g} U$ content in the same range as the unleached solids samples, it had to be used in a single-point calibration.

The determination of the random driver-measured uranium value with this single standard generally gave good results over the range of 150 to $500 \mathrm{~g}$. Counting statistics ( 5\%) was the major uncertainty in the random driver measurement. This made it difficult to determine whether corrected or uncorrected count rates yielded the best results because the net flux and density corrections were on the order of 1 to $2 \%$. Results for twelve of the samples are shown in Figure 13. These data have not been corrected with the flux and density corrections. 


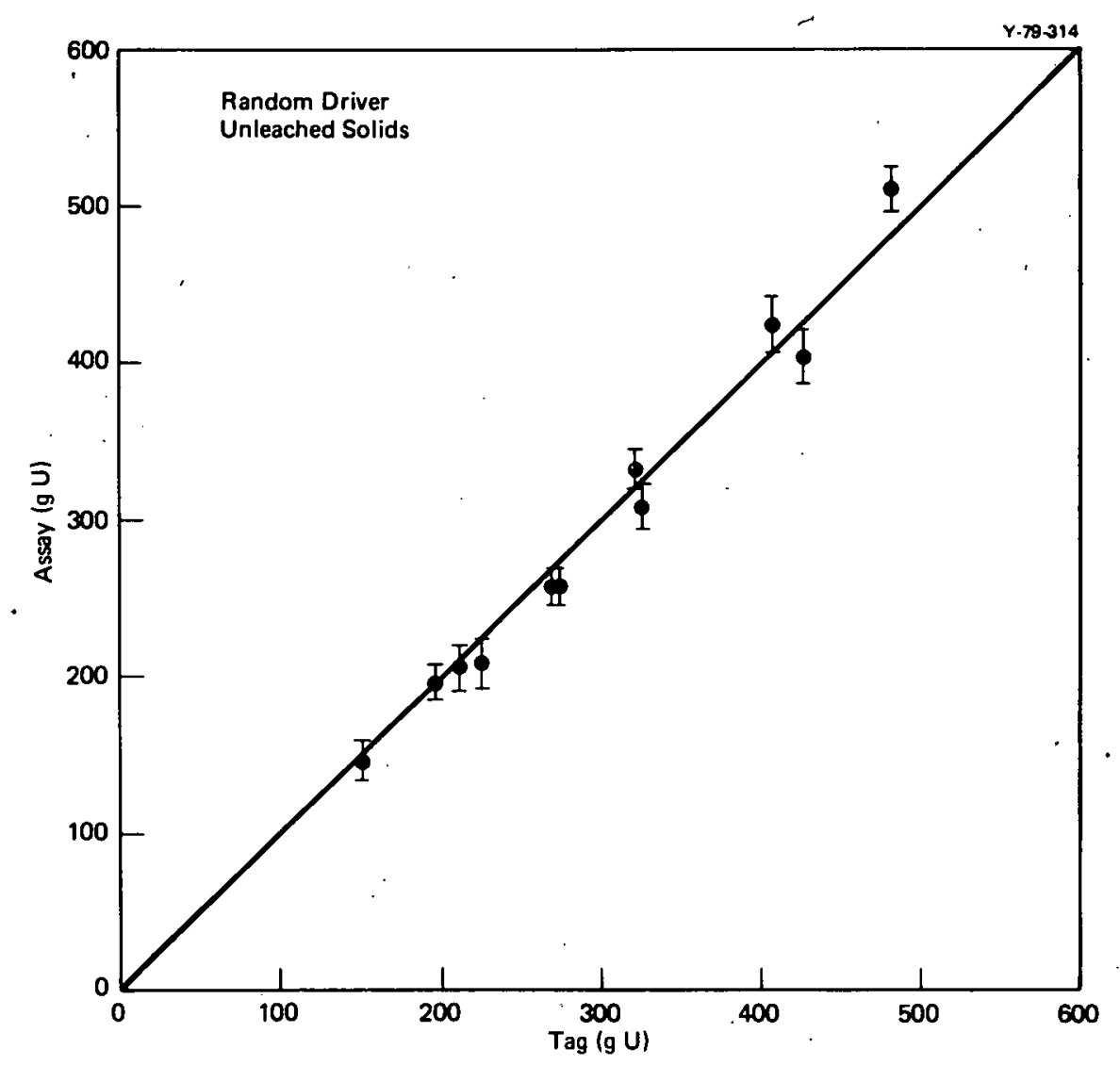

Figure 13. RANDOM DRIVER ASSAY RESULTS FOR UNLEACHED SOLIDS: (Straight line is a line of equal values. Data have not been corrected for flux and density effects.)

A second counting technique involved repeated counting of the unknown for 2000 to $4000 \mathrm{sec}$, with the 878-gram skull oxide standard counted once before each series of cycles. From 5 to 12 counting cycles were taken on each sample. Results from the two methods are compared in Table 7 for 12 samples. The better statistical precision of the cycled data results from a longer counting time and a larger number of samples than the data taken with periodic calibration update. For both counting methods, the corrected coincidence (using flux and density corrections) gives better results than the uncorrected (temperature corrected coincidence rates). This shows that for this specific case the LASL attempt at making random driver results independent of standard type was successful. It also indicates that the 878-gram $\mathrm{U}_{3} \mathrm{O}_{8}$ skull oxide sample can be used as a standard for counting unleached solids with an overall bias of less than $1 \%$.

Precision of the Sampling, Chemical, and Isotopic Analyses

The above results indicating random driver accuracy in the range of $1 \%$ or better are only meaningful when compared to the present laboratory methods in use. These involve sampling the material and performing chemical and mass spectrographic analyses. The mass 
Table 7

UNLEACHED SOLIDS ASSAY RESULTS

\begin{tabular}{|c|c|c|c|c|c|}
\hline \multirow[b]{2}{*}{$\cdot$} & \multirow[b]{2}{*}{$\begin{array}{l}\text { Tag } \\
(\mathrm{g} \cup)\end{array}$} & \multicolumn{2}{|c|}{ Method $1^{(1)}$} & \multicolumn{2}{|c|}{ Method $2^{(2)}$} \\
\hline & & $\begin{array}{l}\text { Corrected } \\
\text { Coincidence } \\
\text { (g U) }\end{array}$ & $\begin{array}{l}\text { Temperature } \\
\text { Corrected } \\
\text { Coincidence } \\
(\mathrm{g} \mathrm{U})\end{array}$ & $\begin{array}{c}\text { Corrected } \\
\text { Coincidence } \\
\text { (g U) }\end{array}$ & $\begin{array}{c}\text { Temperature } \\
\text { Corrected } \\
\text { Coincidence } \\
(g U)\end{array}$ \\
\hline & 198 & $207.0 \pm 3.6$ & $203.6 \pm 3.8$ & $197.4 \pm 7.2$ & $194.5 \pm 7.0$ \\
\hline & 210 & $196.4 \pm 7.6$ & $194.2 \pm 7.2$ & $199.9 \pm 4.6$ & $197.8 \pm 4.6$ \\
\hline & 213 & $204.4 \pm 14$ & $199.3 \pm 13$ & $217.8 \pm 7.5$ & $212.4 \pm 7.5$ \\
\hline & 230 & $226.4 \pm 23$ & $221.4 \pm 22$ & $238.6 \pm 60$ & $232.9 \pm 6$ \\
\hline & 244 & $252.5 \pm 19$ & $257.6 \pm 19$ & $266.4 \pm 11$ & $270.5 \pm 11$ \\
\hline & 254 & $260.9 \pm 23$ & $259.5 \pm 23$ & $260.7 \pm 7.5$ & $259.8 \pm 7.5$ \\
\hline & 316 & $301.9 \pm 15$ & $287.0 \pm 14$ & $316.6 \pm 3.9$ & $300.8 \pm 3.9$ \\
\hline & 317 & $324.0 \pm 10$ & $310.4 \pm 9.5$ & $316.7 \pm 5.1$ & $303.8 \pm 4.8$ \\
\hline & 317 & $314.0 \pm 20$ & $310.7 \pm 20$ & $314.0 \pm 5.4$ & $310.2 \pm 5.4$ \\
\hline & 327 & $300.5 \pm 6.1$ & $297.1 \pm 5.6$ & $298.7 \pm 6.3$ & $295.6 \pm 6.3$ \\
\hline & 396 & $402.0 \pm 15$ & $396.6 \pm 14$ & $402.4 \pm 7.2$ & $397.4 \pm 7.2$ \\
\hline & 397 & $397.7 \pm 16$ & $385.7 \pm 15$ & $395.1 \pm 3.5$ & $381.3 \pm 3.2$ \\
\hline Totals & 3419 & $3387.7 \pm 54$ & $3322.1 \pm 52$ & $3424.3 \pm 23$ & $3357.0 \pm 23$ \\
\hline \multicolumn{6}{|c|}{ Mean Deviation (\%) } \\
\hline (Ass & $\mathrm{ag} / / \mathrm{Tag}$ & -0.92 & -2.83 & 0.16 & -1.81 \\
\hline \multicolumn{6}{|c|}{$\begin{array}{l}\text { Mean Difference of } \\
\text { Individual } \\
\text { Measurements (g) }\end{array}$} \\
\hline (Ass & & -2.75 & -8.00 & 0.50 & -5.25 \\
\hline$\sigma_{\text {mean }}$ & ence $(\%)$ & 3.3 & 3.9 & 3.5 & 4.1 \\
\hline
\end{tabular}

(1) Method 1: Calibration update every third sample. Average August 4th data sets \pm standard deviation.

(2) Method 2: Repeated cycling of sample, average of 5-12 cycles. Mean \pm standard deviation.

spectrographic analysis is required because the material is not of constant enrichment. A nonhomogeneous blending of the material can induce errors in the mass spectrographic results as well as the uranium concentration results.

To check the precision of typical results expected from this technique, twelve cans of unleached solids were resampled and reanalyzed for uranium content and percent $235 \mathrm{U}$. The $235 \mathrm{U}$ content measurements before and after the resampling were compared. The standard deviation of these paired observations was found to be $4.35 \mathrm{~g} 235 \mathrm{U}$ (average $235 \mathrm{U}$ content $-300 \mathrm{~g}$ ) for a percentage relative standard deviation of about $1.5 \%$ :

This precision is somewhat better than that exhibited by the random driver, which is limited by counting statistics ( 3 to $6 \%$ ) for this mass range (200 to $400 \mathrm{~g} \mathrm{U}$ ) for $1000 \mathrm{sec}$ count times. Increasing the count time significantly is not practical. These figures lead to a practical lower limit for the assay of approximately $90 \%$ enriched uranium of about $100 \mathrm{~g} \mathrm{U}$, which yields a statistical precision of about $9 \%(1 \sigma)$ tor a 2000 -sec count time. 
Random driver precision will not be greatly affected by a lack of exact $235 U$ isotopic content. The 24 unleached ash samples studied had a mean $235 \mathrm{U}$ content of $90 \%$, with a relative standard deviation of $1.5 \%$. If this $1.5 \%$ uncertainty is folded with a typical $4 \%$ uncertainty from counting statistics, the resulting precision is $4.3 \%$ at the $1 \sigma$ level. This enables the random driver to be used on unleached solids to give immediate results with an accuracy on the order of 1 to $2 \%$ and a precision of better than $5 \%$ at the $1 \sigma$ level. 


\section{CONCLUSIONS}

The random driver has been demonstrated to provide rapid, accurate, and nondestructive verification and measurement of the uranium content of $\mathrm{U}_{3} \mathrm{O}_{8}$ skull oxide and unleached solids. For both material types, systematic errors (bias) are less than $1 \%$. For skull oxide, the instrument exhibits a precision of about 3\% $(1 \sigma)$, being limited by short-term instrument instabilities. This precision is equivalent to that exhibited by routine sampling and chemical analysis: Samples from the EWing casting area with constant enrichment require no additional measurements. The total sample-analysis time for a typical $8-\mathrm{kg}$ uranium skull oxide sample is about ten minutes.

The precision of a 1000-sec measurement on a typical 300-g $U$ unleached solids sample is about $4 \%$ at the $1 \sigma$ level, being limited by counting statistics. Uncertainty in the $235 \mathrm{U}$ enrichment (if no mass spectrometer measurements are available) will add only slightly to this value.

The complex and sophisticated character of the random driver makes it susceptible to maintenance problems. Its modular design can reduce potential problems if spare modules are available. A maintenance plan should be formed which would minimize the downtime associated with the failure of components that cannot easily be repaired at $Y-12$. The instrument requires supervision by knowledgeable, experienced personnel. Computerprompted dialogue enables the system to be operated with minimal training.

The evaluation program will continue with measurements on other material types including pure $\mathrm{UO}_{2}, \mathrm{UO}_{3}, \mathrm{UF}_{4}$, and machine turnings. 


\section{REFERENCES}

1. Bowers, G. L., Darby, D. M., Dunigan, T. H., Sampson, T. E., and Cochran, J. L.; Development Aspects of a Dynamic Special Nuclear Materials Control and Accountability System, Y/DA-7740; Union Carbide Corporation-Nuclear Division, Oak Ridge Y-12 Plant, Oak Ridge, Tennessee.

2. Keepin, G. R.; Program Status Report, January through April 1971, Nuclear Safeguards Research and Development, LA-4705-MS; Los Alamos Scientific Laboratory, Los Alamos, New Mexico (May 1971).

3. Keepin, G. R.; Program Status Report, May through August 1971, Nuclear Safeguards Research and Development, LA-4794-MS; Los Alamos Scientific Laboratory, Los Alamos, New Mexico (October 1971).

4. Keepin, G. R.; Program Status Report, September through December 1971, Nuclear Safeguards Research and Development, LA-4883-PR; Los Alamos Scientific Laboratory, Los Alamos, New Mexico (March 1972).

5. Keepin, G. R.; Program Status Report, January through April 1972; Nuclear Safeguards Research and Development, LA-4994-PR; Los Alamos Scientific Laboratory, Los Alamos, New Mexico (July 1972).

6. Keepin, G. R.; Program Status Report, May through August 1972, Nuclear Safeguards Research and Development, LA-5091-PR; Los Alamos Scientific Laboratory, Los Alamos, New Mexico (November 1972).

7. Keepin, G. R.; Program Status Report, September through December 1972, Nuclear Safeguards Research and Development, LA-5197-PR; Los Alamos Scientific Laboratory, Los Alamos, New Mexico (March 1973).

8. Keepin, G. R.; Program Status Report, January through April 1973, Nuclear Safeguards Research and Development, LA-5291-PR; Los Alamos Scientific Laboratory, Los Alamos, New Mexico (May 1973).

9. Keepin, G. R.; Program Status Report, May through August 1973, Nuclear Safeguards Research and Development, LA-5431-PR; Los Alamos Scientific Laboratory, Los Alamos, New Mexico (November 1973).

10. Keepin, G. R.; Program Status Report, September through December 1973, Nuclear Safeguards Research and Development, LA-5557-PR; Los Alamos Scientific Laboratory, Los Alamos, New Mexico (February 1974).

11. Keepin, G. R.; Program Status Report, January through April 1974, Nuclear Safeguards Research and Development, LA-5675-PR; Los. Alamos Scientific Laboratory, Los Alamos, New Mexico (August 1974). 
12. Program Status Report, September through December 1974, Nuclear Safeguards Research and Development, LA-5889-PR; Los Alamos Scientific Laboratory, Los Alamos, New Mexico (April 1975).

13. Program Status Report, January through April 1975, Nuclear Safeguards Research and Development, LA-6040-PR; Los Alamos Scientific Laboratory, Los Alamos, New Mexico (August 1975).

14. Program Status Report, May through August 1975, Nuclear Safeguards Research and Development, LA-6142-PR; Los Alamos Scientific Laboratory, Los Alamos, New Mexico (December 1975).

15. Program Status Report, September through December 1975, Nuclear Safeguards Research and Development, LA-6316-PR; Los Alamos Scientific Laboratory, Los Alamos, New Mexico (April 1976).

16. Program Status Report, May through August 1976, Nuclear Safeguards Research and Development, LA-6675-PR; Los Alamos Scientific Laboratory, Los Alamos, New Mexico (January 1977).

17. Sapir, J. L.; Program Status Report, January through April 1977, Nuclear Safeguards Research and Development, LA-6849-PR; Los Alamos Scientific Laboratory, Los Alamos, New Mexico (August 1977).

18. Sapir, J. L.; Program Status Report, September through December 1977, Nuclear Safeguards Research and Development, LA-7211-PR; Los Alamos Scientific Laboratory, Los Alamos, New Mexico (July 1978).

19. Foley, J. E.; Application of the Random Source Interrogation System (Random Driver) at the Oak Ridge Y-12 Plant. Preliminary Results. LA-5078-MS; University of California, Los Alamos Scientific Laboratory (November 1972).

20. Ensslin, N.; Los Alamos Scientific Laboratory, Personal Communication. 


\section{ACKNOWLEDGMENTS}

) Numerous people have contributed to this evaluation program. W. H. Tipton has provided guidance and encouragement throughout the program. H. R. Butler and his staff, especially M. B. Potter, have provided the material and blending and sampling for numerous laboratory analyses. E. E. Johnson performed the statistical analysis of the data. J. L. Cochran and G. D. Ellis were the principal investigators during the initial phases of the program. 


\section{Distribution}

Department of Energy - Oak Ridge

Hickman, H. D.

Leed, R. E.

Poteat, R. M.

Lawrence Livermore Laboratory

Arnold, W. F.

Los Alamos Scientific Laboratory

Hoyt, H. C.

Sompson, T. E.

Oak Ridge Gaseous Diffusion Plant

Armstrong, R. C.

Stief, S. S.

Wilcox, W. J., Jr

Oak Ridge National Laboratory

Hopkins, C. C.

Oak Ridge Y-12 Plant

Borge, H. C.

Butler, H. R.

Cochran, J. L.

Dodson, W. H./Googin, J. M.

Ebert, J.W.

Fraser, R. J.

Harding, J. E.

Hogue, $H$. $H$.

Jünisurn, E. E.

Keith, A.

Kite, H. T.

Phillips, L. R.

Smith, U.W.

Smith, R. D.

Sriow, S. G:

Ward, M. N.

Y-12 Central Files (master copy)

$Y-12$ Central Files (route copy)

$Y-12$ Central Files ( $Y-12 R C)$

$Y-12$ Central Files (5)
Paducah Gaseous Diffusion Plant

Bewley, H. D.

Sandia-Livermore

Spencer, W. J.

Union Carbide Corporation - New York

Tinsley, S. W.

In addition, this report is distributed in accordance with the Category UC-15, Safeguards - Nuclear Materials Security, as given in the Standard Distribution for Unclassified Scientific and Technical Reports, DOE/TIC-4500. 